\title{
Estradiol Rapidly Attenuates ORL-1 Receptor-Mediated Inhibition of Proopiomelanocortin Neurons via $\mathbf{G}_{\mathbf{q}}$-Coupled, Membrane-Initiated Signaling
}

\author{
Kristie Conde $^{a}$ Cecilia Meza $^{b}$ Martin J. Kelly ${ }^{c}$ Kevin Sinchak ${ }^{d}$ \\ Edward J. Wagner ${ }^{a, b}$ \\ ${ }^{a}$ Graduate College of Biomedical Sciences and ${ }^{b}$ Department of Basic Medical Sciences, College of Osteopathic \\ Medicine, Western University of Health Sciences, Pomona, Calif., ' Department of Physiology \& Pharmacology, \\ Oregon Health \& Science University, Portland, Oreg., and d Department of Biological Sciences, California State \\ University, Long Beach, Long Beach, Calif., USA
}

\section{Key Words}

Estradiol · Proopiomelanocortin · Orphanin FQ .

Opioid receptor-like-1 $\cdot$ Sexual receptivity .

Phosphatidylinositol-3-kinase

\begin{abstract}
Estradiol rapidly regulates the activity of arcuate nucleus (ARH) proopiomelanocortin (POMC) neurons that project to the medial preoptic nucleus (MPN) to regulate lordosis. Orphanin $\mathrm{FQ} /$ nociceptin $(\mathrm{OFQ} / \mathrm{N})$ acts via opioid receptor-like (ORL)-1 receptors to inhibit these POMC neurons. Therefore, we tested the hypothesis that estradiol excites POMC neurons by rapidly attenuating inhibitory ORL- 1 signaling in these cells. Hypothalamic slices through the ARH were prepared from ovariectomized rats injected with Fluorogold into the MPN. Electrophysiological recordings were generated in ARH neurons held at or near $-60 \mathrm{mV}$, and neuronal phenotype was determined post hoc by immunohistofluorescence. OFQ/N application induced robust outward currents and hyperpolarizations via $G$ protein-gated, inwardly rectifying $\mathrm{K}^{+}(\mathrm{GIRK})$ channels that were attenuated by pretreatment with either 17- $\beta$ estradiol $\left(E_{2}\right)$ or $E_{2}$ conjugated to bovine serum albumin. This was blocked by the estrogen receptor (ER) antagonist ICI 182,780 and mimicked by the $\mathrm{G}_{\mathrm{q}^{-}}$
\end{abstract}

\section{KARGER}

(๑) 2016 S. Karger AG, Base

0028-3835/16/1036-0787\$39.50/0

E-Mail karger@karger.com

www.karger.com/nen coupled membrane ER $\left(\mathrm{G}_{\mathrm{q}}-\mathrm{mER}\right)$ ligand STX and the ERa agonist PPT. Inhibiting phosphatidylinositol-3-kinase (PI3K) blocked the estrogenic attenuation of ORL-1/GIRK currents. Antagonizing either phospholipase C (PLC), protein kinase $C$ $(\mathrm{PKC})$, protein kinase $A(P K A)$ or neuronal nitric oxide synthase (nNOS) also abrogated $E_{2}$ inhibition of ORL-1/GIRK currents, whereas activation of PKC, PKA, protein kinase $B$ (Akt) and nNOS substrate L-arginine all attenuated the OFQ/N response. This was observed in $92 \mathrm{MPN}$-projecting, POMC-positive $A R H$ neurons. Thus, ORL-1 receptor-mediated inhibition of POMC neurons is rapidly and negatively modulated by $E_{2}$, an effect which is stereoselective and membrane initiated via $G_{q}-m E R$ and ERa activation that signals through PLC, PKC, PKA, PI3K and nNOS.

๑) 2016 S. Karger AG, Basel

\section{Introduction}

$17 \beta$-Estradiol $\left(\mathrm{E}_{2}\right)$ exerts far-reaching effects on numerous biological systems. It is primarily synthesized in the ovaries, although small amounts are produced in other tissues (e.g. adrenal cortex, adipose tissue). Recent evidence suggests that it is also manufactured in the presynaptic bouton, where it could thus function as a neuro- 
steroid [1]. In the female, levels of estrogen fluctuate naturally during the course of the estrous cycle. These fluctuations are responsible for numerous physiological and behavioral changes, including ovulation, uterine development and sexually receptive behavior (lordosis) [2] This dynamic hormone also contributes to the maintenance of bone density, smooth muscle tone, memory, appetite and the coordination of female sexual behavior to optimize the likelihood of fertilization and implantation $[3,4]$. Our laboratories have been investigating the temporal pattern of estrogen receptor (ER) signaling by $E_{2}$ using ovarian steroid-responsive hypothalamic opioid circuits in the rat that regulate sexual receptivity.

As mentioned above, $\mathrm{E}_{2}$ is vital in the coordination of female sexual behavior, also known as lordosis or 'presenting', which is associated with copulation. The primary characteristics of lordosis are a lowering of the forelimbs with the rear limbs extended and hips raised, a lifting of the head, ventral arching of the spine and a movement of the tail to one side [5-7]. Initially, $\mathrm{E}_{2}$ inhibits sexual receptivity during the metestrus/diestrus phase of the rodent ovarian cycle. This initial inhibition is required for subsequent sexual behavior. Shortly after $\mathrm{E}_{2}$ peaks during early proestrus, progesterone will peak along with a $\mathrm{LH}$ and FSH surge; resulting in ovulation during late proestrus. These hormonal fluctuations set the stage for subsequent lordotic behavior during the estrus phase that optimizes the likelihood for fertilization and subsequent implantation $[8,9]$. This natural cyclicity of female reproductive behavior is mimicked using a well-established ovariectomized female rat model $[6,10,11]$. Whereas low priming doses of $E_{2}$ (e.g., $2 \mu \mathrm{g}$ ) alone inhibit lordotic behavior; they induce it when they are followed by progesterone $(500 \mu \mathrm{g}) 26 \mathrm{~h}$ later. This regulation of behavior is occurring through multiple receptor signaling mechanisms, all of which appear to converge on hypothalamic arcuate nucleus (ARH) proopiomelanocortin (POMC) neurons that project to the medial preoptic nucleus (MPN) [12-14]. The initial inhibition of lordosis caused by low levels of $\mathrm{E}_{2}$ is due to the excitation of these POMC neurons. This leads to an overriding tone of opioid activity that is inhibitory to lordotic behavior, confirmed in $\mu$-opioid receptor-null mice or in rats pretreated intracerebroventricularly or site specifically into the MPN with the opioid receptor antagonist naloxone. In both instances, subsequent sexual receptivity was significantly inhibited in $\mathrm{E}_{2}$-primed, progesterone-treated females $[7,11]$. This action is vital to the appropriate timing and subsequent expression of female sexual behavior.

The initial inhibition of sexual receptivity is ER mediated. However, there are many different subtypes of ER, including $E R \alpha, E R \beta$, G-protein coupled receptor-30 (GPR30) and a $\mathrm{G}_{\mathrm{q}}$-coupled membrane $\mathrm{ER}\left(\mathrm{G}_{\mathrm{q}}\right.$-mER), all of which have been implicated in playing some role in sexual behavior. For example, the ERa agonist PPT causes a clear change in sexual proceptive and receptive behavior (e.g., ear wiggling, hops and darts, lordosis quotient and decreased rejection), as well as increased [3H]-inositol phosphate accumulation in the rat uterus, to a similar degree as seen with $\mathrm{E}_{2}$ treatment $[15,16]$. This sexual behavior is not seen upon administration of the ER $\beta$ agonist diarylpropionitrile (DPN) [15]. When given simultaneously, however, DPN was able to modulate the activity of the PPT by eliminating the PPT-induced increase in expression of both receptive and proceptive female sexual behavior [15]. Furthermore, mice that lack ERa have stunted uterine development that results in infertility, whereas mice that lack ER $\beta$, experience normal uterine development [17]. These ERa-mediated effects on sexual receptivity are due, at least in part, to membrane-delimited interactions with specific metabotropic glutamate receptors $[12,14,18]$. Another route for estrogenic modulation is the GPR30 receptor [19]. GPR30 binds $E_{2}$ with high affinity, has been found to be involved in the rapid actions elicited by $E_{2}$ in peripheral reproductive tissue and activates the extracellular signal-regulated kinase (ERK) pathway independently of ER $\alpha$ or ER $\beta$ [20]. Moreover, GPR30 is expressed in the ARH and in EB-primed rats. $E_{2}$ acting through GPR30 in the ARH can deactivate $\mu$-opioid receptors in the MPN to facilitate lordosis within $30 \mathrm{~min}$ [21]. $\mathrm{E}_{2}$ and the highly potent and selective agonist STX also activate another, more recently characterized $G_{\mathrm{q}}-\mathrm{mER}$. Similar to ERa, activation of the $\mathrm{G}_{\mathrm{q}}-\mathrm{mER}$ with STX increases intracellular $\mathrm{Ca}^{2+}$ levels and neuroprogesterone synthesis in hypothalamic astrocytes [22], stimulates MPN-projecting POMC neurons and elicits lordosis behavior in $\mathrm{E}_{2}$-primed females [13].

Rapid membrane-initiated signaling following activation of either $\mathrm{ER} \alpha$ or $\mathrm{G}_{\mathrm{q}}$-mER triggers a signal transduction cascade involving phospholipase $\mathrm{C}$ (PLC), protein kinase $\mathrm{C}$ (PKC), protein kinase A (PKA), as well as phosphatidylinositol-3-kinase (PI3K), that significantly disrupts the ability of metabotropic, $\mathrm{G}_{\mathrm{i} / \mathrm{o}}$-coupled receptors such as the $\mu$-opioid and $\mathrm{GABA}_{\mathrm{B}}$ receptors to activate inhibitory, $\mathrm{G}$ protein-gated, inwardly rectifying $\mathrm{K}^{+}$(GIRK) channels in ARH POMC neurons [3, 12, 23]. It is suggested that this uncoupling of metabotropic, $\mathrm{G}_{\mathrm{i} / \mathrm{o}}$-coupled receptors from their GIRK channels occurs via PKAmediated phosphorylation in ARC POMC neurons [24]. This leads to the excitation of the ARH POMC neurons and the release of POMC-derived peptides like $\beta$-en- 
dorphin $[25,26]$. Moreover, rapid estrogenic signaling also occurs in GABAergic, gonadotropin-releasing hormone $(\mathrm{GnRH})$ and $A_{12}$ dopamine neurons in the hypothalamus, which indicates that this rapid signaling is critical for normal estrogenic control of homeostatic functions [27-29].

Another likely substrate through which $\mathrm{E}_{2}$ rapidly modulates the activity of POMC neurons is the orphanin $\mathrm{FQ} /$ nociceptin (OFQ/N)-opioid receptor-like (ORL)-1 system. OFQ/N is the endogenous ligand that binds to its cognate ORL-1 receptor, which is heavily expressed in neuronal populations throughout the mediobasal hypothalamus including MPN-projecting POMC neurons [30-32]. Like the $\mathrm{GABA}_{B}$ and $\mu$-opioid receptors, the ORL-1 receptor is a metabotropic, $\mathrm{G}_{\mathrm{i} / \mathrm{o}}$ coupled receptor. The binding of OFQ/N to the ORL-1 receptor elicits a very robust, reversible outward current and hyperpolarization in ARH POMC neurons that can be antagonized by the GIRK channel blockers $\mathrm{Ba}^{2+}$ and tertiapin [33-35]. In addition, it can presynaptically inhibit the excitatory glutamatergic input impinging upon these cells [35]. We know that in vivo $E_{2}$ priming negatively modulates the postsynaptic inhibitory effects of ORL-1 activation on POMC neurons that project to the MPN, as well as the presynaptic inhibition of glutamate release onto them [35]. As mentioned above, there is compelling precedence for rapid estrogenic attenuation of metabotropic, $\mathrm{G}_{\mathrm{i} / \mathrm{o}}$-coupled receptors like the $\mathrm{GABA}_{\mathrm{B}}, \mu$-opioid and cannabinoid $\mathrm{CB} 1$ receptors from their effector systems. There is also a burgeoning yet incomplete understanding of the signaling molecules such as PLC, PKC, PKA and neuronal nitric oxide synthase (nNOS) through which this process takes place $[36,37]$. Moreover, recent evidence indicates that $E_{2}$ rapidly attenuates ORL-1 receptor-mediated antinociception via an ERK2-dependent mechanism [38]. We therefore tested the hypothesis that $\mathrm{E}_{2}$ rapidly attenuates the ORL-1 receptor-mediated activation of inhibitory GIRK channels in MPN-projecting POMC neurons that control female sexual receptivity via multiple ER receptor subtypes and signal transduction mechanisms.

\section{Materials and Methods}

Animals

Adult female Long-Evans rats (200-225g) were purchased from Charles River Laboratory Inc. (Wilmington, Mass., USA). Bilateral ovariectomies were performed by the supplier. The rats were 8-12 weeks of age at the time of ovariectomy, and were shipped to us 1 week later. After 1 week of quarantine, the rats re- ceived their Fluorogold injection (see below), and 1 week later were used for experimentation. Thus, a total of 3 weeks had elapsed between the ovariectomies and the electrophysiology experiments (see below). Upon arrival, they received a $2-\mu \mathrm{g}$ priming dose of estradiol benzoate in order to help maintain steroid sensitivity. Rats were housed under a 12:12-hour light/dark cycle, with food and water available ad libitum. All procedures were approved by the Western University of Health Sciences IACUC in accordance with institutional guidelines based on NIH standards.

\section{Drugs}

For the electrophysiological experiments described below, all drugs used were purchased from Tocris Bioscience (Minneapolis, Minn., USA) unless stated otherwise. Tetrodotoxin (TTX; $\mathrm{Na}^{+}$ channel blocker; Alomone Labs, Jerusalem, Israel) was prepared as a $1 \mathrm{mM}$ stock solution in UltraPure $\mathrm{H}_{2} \mathrm{O}$ and diluted further with artificial cerebrospinal fluid (aCSF) to the working concentration of $500 \mathrm{nM}$. OFQ/N was prepared as a $1 \mathrm{mM}$ stock solution in UltraPure $\mathrm{H}_{2} \mathrm{O}$ and diluted further with aCSF to the working concentration of $1 \mu \mathrm{M}$.

$\mathrm{E}_{2}$ (Steraloids, Newport, R.I., USA) was prepared as a $1 \mathrm{mM}$ stock solution in punctilious ethanol and diluted further with aCSF to the working concentration of $100 \mathrm{nM}$. 17a-estradiol (17a- $\mathrm{E}_{2}$; Steraloids) was prepared as a $1 \mathrm{~mm}$ stock solution in punctilious ethanol and diluted further with aCSF to the working concentration of $100 \mathrm{nM}$. The membrane impermeant $\mathrm{E}_{2} 17$ hemisuccinate-bovine serum albumin ( $\mathrm{E}_{2}$-BSA; Steraloids) was prepared as a $1 \mathrm{mM}$ stock solution in dimethyl sulfoxide (DMSO) and diluted further with aCSF to the working concentration of $100 \mathrm{nM}$. The ER antagonist $7 \alpha, 17 \beta-[9-[(4,4,5,5,5$-pentafluoropentyl)sulfinyl $]$ nonyl] estra-1,3,5(10)-triene-3,17-diol (ICI 182,780) was prepared as a $1 \mathrm{mM}$ stock solution in punctilious ethanol and diluted further with aCSF to the working concentration of $1 \mu \mathrm{M}$.

STX (synthesized by AAPharma Syn, Ann Arbor according to the Tobias et al., ChemMedChem 2006 protocol) was prepared as a $1 \mathrm{mM}$ stock solution in DMSO and further diluted with aCSF to the working concentration of $10 \mathrm{nM}$. The ERa agonist $4,4^{\prime}, 4^{\prime \prime}-(4-$ propyl-[1H]-pyrazole-1,3,5-triyl)trisphenol (propyl pyrazole tri$\mathrm{ol} / \mathrm{PPT}$ ) was prepared as a $10 \mathrm{mM}$ stock solution in punctilious ethanol and diluted further with aCSF to the working concentration of $1 \mu \mathrm{M}$. The GPR30 agonist $( \pm)-1-\left[\left(3 \mathrm{a} R^{*}, 4 S^{*}, 9 \mathrm{~b} S^{*}\right)-4-\right.$ (6-bromo-1, 3-benzodioxol-5-yl)-3a,4,5,9b-tetrahydro-3H-cyclopenta[c] quinolin-8-yl]-ethanone (G1) was prepared as a $10 \mathrm{~mm}$ stock solution in DMSO and diluted further with aCSF to the working concentration of $3 \mu \mathrm{M}$. The ER $\beta$ agonist 2,3-bis(4hydroxyphenyl)-propionitrile (DPN) was prepared as a $10-\mathrm{mM}$ stock solution in punctilious ethanol and diluted further with aCSF to the working concentration of $3 \mu \mathrm{M}$.

The PI3K inhibitor 2-(4-morpholinyl)-8-(4-aminopheny) 1-4H-1-benzopyran-4-one (PI828) was prepared as a $10 \mathrm{mM}$ stock solution in DMSO and further diluted with aCSF to the working concentration of $10 \mu \mathrm{M}$. The PLC inhibitor 1-[6-[[(17 $\beta)$ 3-methoxyestra-1, 3, 5(10)-trien-17-yl]amino]hexyl]-1H-pyrrole2,5-dione (U73122) was prepared as a $20 \mathrm{mM}$ stock solution in DMSO and further diluted with aCSF to the working concentration of $20 \mu \mathrm{M}$. The inactive U73122 analog 1-[6-[[(17 $\beta)-3-$ methoxyestra-1,3, 5(10)-trien-17-yl] amino]hexyl]-2,5-pyrrolidinedione (U73343) was prepared as a $20 \mathrm{mM}$ stock solution in DMSO and further diluted with aCSF to the working concentration of 20 $\mu \mathrm{M}$. The PKC inhibitor (S)-2,6-diamino-N-[(1-(1-oxotridecyl)- 
2-piperidinyl)methyl]hexanamide dihydrochloride hydrate (NPC 15437) was prepared as a $30 \mathrm{~mm}$ stock solution in DMSO and diluted further with aCSF to the working concentration of $30 \mu \mathrm{M}$. The $\mathrm{PKC}$ activator phorbol 12,13-dibutyrate (PDBu) was prepared as a $10 \mathrm{mM}$ stock solution in DMSO and further diluted with aCSF to the working concentration of $1 \mu \mathrm{M}$. The PKA inhibitor $(9 R, 10 S, 12 S)-2,3,9,10,11,12$-hexahydro-10-hydroxy-9-methyl1-oxo-9,12-epoxy-1H-diindolo[1,2,3-fg: $\left.3^{\prime}, 2^{\prime}, 1^{\prime}-k l\right]$ pyrrolo[3, 4-i] $[1,6]$ benzodiazocine-10-carboxylic acid, hexyl ester (KT5720) was prepared as a $300 \mu \mathrm{M}$ stock solution in DMSO and further diluted with aCSF to the working concentration of $300 \mathrm{nM}$. The PKA activator, (S)-adenosine, cyclic $3^{\prime}, 5^{\prime}$-(hydrogen phosphorothioate) triethylammonium (Sp-cAMP) was prepared as a $10 \mathrm{mM}$ stock solution in UltraPure $\mathrm{H}_{2} \mathrm{O}$ and diluted further with aCSF to the working concentration of $100 \mu \mathrm{M}$. The nNOS inhibitor N5[imino(propylamino)methyl]-L-ornithine hydrochloride (N-propyl-L-arginine; NPLA) was prepared as a $10 \mathrm{mM}$ stock solution in UltraPure $\mathrm{H}_{2} \mathrm{O}$ and further diluted with aCSF to the working concentration of $10 \mu \mathrm{M}$. The endogenous NOS substrate L-arginine was prepared as a $30 \mathrm{mM}$ stock solution in UltraPure $\mathrm{H}_{2} \mathrm{O}$ and diluted further with aCSF to the working concentration of $30 \mu \mathrm{M}$. The Akt activator 2-amino-6-chloro- $\alpha$-cyano-3-(ethoxycarbonyl)$4 H$-1-benzopyran-4-acetic acid ethyl ester (SC 79) was prepared as a $10 \mathrm{mM}$ stock solution in DMSO and diluted further with aCSF to the working concentration of $10 \mu \mathrm{M}$.

\section{Stereotactic Surgery}

All animals were focally injected with the retrograde tracer Fluorogold (Fluorochrome, LLC, Denver, Colo., USA) into the MPN 6-8 days prior to experimentation. They were fitted in a stereotactic apparatus (Digital Lab Standard; Stoelting Co., Wood Dale, Ill., USA) while under $3 \%$ isoflurane anesthesia. The scalp was opened with a 2 - to $2.5-\mathrm{cm}$ incision made down the midline of the skull, beginning at the front of the orbits towards the occipital lobe with a scalpel blade. The periosteum was rubbed from the scalp by sterile cotton-tipped applicators. A single hole was drilled, so that an injection needle could be slowly lowered into the MPN [coordinates from bregma, anterior, $( \pm) 0.1 \mathrm{~mm}$; lateral, $-0.75 \mathrm{~mm}$; ventral, $-6.0 \mathrm{~mm}$ from dura; tooth bar, $-3.3 \mathrm{~mm}$ ]. The injection needle was held at these coordinates for $1 \mathrm{~min}$ before the start of infusion. The retrograde tract tracer Fluorogold (5\% dissolved in sterile saline; $0.7 \mu$ l total volume) was injected slowly, over a period of $6 \mathrm{~min}$, into the MPN using a Stoelting manual injector system. The injection needle remained in place for an additional $2 \mathrm{~min}$ after infusion to allow for diffusion from the tip and then slowly removed from the brain to reduce potential spread of Fluorogold. Sterile bone wax was placed in the hole to seal the cavity and help promote clotting. After surgery, the rats were given oral antibiotics in drinking water $(0.5 \mathrm{mg} / \mathrm{ml}$ of sulphamethoxazole and $0.1 \mathrm{mg} /$ ml of trimethoprim; Hi-Tech Pharmacal, Amityville, N.Y., USA), as well as Carprofen $(5 \mathrm{mg} / \mathrm{kg}$; s.c.; Sigma Aldrich Corp., St Louis, Mo., USA) to help control postoperative pain. Only those animals in which the Fluorogold was injected directly into the MPN were included in the present study.

\section{Tissue Preparation}

On the day of experimentation, the ovariectomized rat was anesthetized with $32 \%$ isoflurane and rapidly decapitated. The brain was removed from the skull and the hypothalamic area was dissected. We then mounted the resultant hypothalamic block on a cutting platform that was secured in a vibratome well filled with ice-cold, oxygenated $\left(95 \% \mathrm{O}_{2}, 5 \% \mathrm{CO}_{2}\right)$ aCSF in which the majority of sodium was replaced by sucrose (sucrose, 208; $\mathrm{NaHCO}_{3}$, 26; $\mathrm{KCl}, 2 ; \mathrm{NaH}_{2} \mathrm{PO}_{4}, 1.25$; dextrose, 10; HEPES, 10; $\mathrm{MgSO}_{4}, 2$; $\mathrm{MgCl}_{2} 1 ; \mathrm{CaCl}_{2}, 1$; in $\left.\mathrm{mM}\right)$. Four to five coronal slices $(300 \mu \mathrm{m})$ through the rostrocaudal extent of the $\mathrm{ARH}$ were then cut at $1{ }^{\circ} \mathrm{C}$. The slices were transferred to an auxiliary chamber containing room-temperature oxygenated aCSF $\left(\mathrm{NaCl}, 124 ; \mathrm{NaHCO}_{3} 26\right.$; dextrose, 10; HEPES, $10 ; \mathrm{KCl}, 5 ; \mathrm{NaH}_{2} \mathrm{PO}_{4}, 2.6 ; \mathrm{MgSO}_{4}, 2 ; \mathrm{CaCl}_{2}$, 1 ; in $\mathrm{mM}$ ) and kept there until electrophysiological recording. Slices were allowed at least $1 \mathrm{~h}$ of recovery before being transferred from the auxiliary chamber to the recording chamber.

\section{Electrophysiology}

During whole-cell patch recording from ARH neurons, slices were maintained in a chamber perfused with a warmed $\left(35^{\circ} \mathrm{C}\right)$, oxygenated aCSF in which the $\mathrm{CaCl}_{2}$ concentration was raised to $2 \mathrm{mM}$. aCSF and all drugs (diluted with aCSF) were perfused via a peristaltic pump at a rate of $1.5 \mathrm{ml} / \mathrm{min}$. Patch electrodes are assembled from borosilicate glass (World Precision Instruments, Sarasota, Fla., USA; $1.5 \mathrm{~mm}$ OD) pulled on a P-97 Flaming Brown puller (Sutter Instrument Co., Novato, Calif., USA) and filled with the following (in $\mathrm{mM}$ ): potassium gluconate, $128 ; \mathrm{NaCl}, 10 ; \mathrm{MgCl}_{2}$, 1; EGTA, 11; HEPES, 10; ATP, 1; GTP, 0.25; 0.5\% biocytin; adjusted to a $\mathrm{pH}$ of 7.3 with $\mathrm{KOH}$. Electrode resistances varied from 3 to $8 \mathrm{M} \Omega$. A Multiclamp 700A preamplifier (Axon Instruments, Foster City, Calif., USA) amplified potentials and passed current through the electrode. Membrane currents were recorded in voltage clamp (and membrane potential in current clamp) with access resistances that typically range from 8 to $22 \mathrm{M} \Omega$, and underwent analog-digital conversion via a Digi-data 1322A interface coupled to pClamp 8.2 software (Axon Instruments). The access resistance $\left(\mathrm{R}_{\mathrm{A}}\right)$, as well as the resting membrane potential and the input resistance $\left(R_{i n}\right)$, were monitored throughout the course of the recording. If the access resistance deviated $>10 \%$ of its original value, the recording was ended. Low-pass filtering of the currents was conducted at a frequency of $2 \mathrm{kHz}$. The liquid junction potential was calculated to be $-10 \mathrm{mV}$ and corrected for during data analysis using pClamp software. Current-voltage (I/V) relationships were generated by administering pulses (10-mV increments; $150-\mathrm{ms}$ duration) ranging from -50 to $-130 \mathrm{mV}$. These were used to calculate OFQ/N-induced changes in slope conductance via linear regression in between -60 and $-80 \mathrm{mV}$ as well as -100 and $-130 \mathrm{mV}$. All recordings were performed from a holding potential of $-60 \mathrm{mV}$.

Baseline I/V relationships were generated after 3 min of perfusion with a solution containing TTX (500 nM) and either (1) vehicle, $E_{2}, 17 a-E_{2}$, or $E_{2}-B S A$; (2) vehicle, one of several ER agonists, or $E_{2}$ plus an ER antagonist, or (3) vehicle, one of several enzyme activators, or $\mathrm{E}_{2}$ plus one of several enzyme inhibitors. After the baseline I/V, the solution was removed and replaced with a second solution containing the same mixture as the first, with the addition of OFQ/N (1 $\mu \mathrm{M})$. The membrane current (or potential) was continuously monitored until a new steady-state is reached, at which time a second I/V relationship is generated. The OFQ/N solution was then removed to allow the aCSF to clear the drugs from the slice. During the washout, the membrane current (or potential) was again monitored until it returned to its original baseline level, at which time a final I/V relationship was taken to ensure reversibility of the OFQ/N-induced effect. A schematic of the protocol for the drug administration is shown in figure 1. Control respons- 


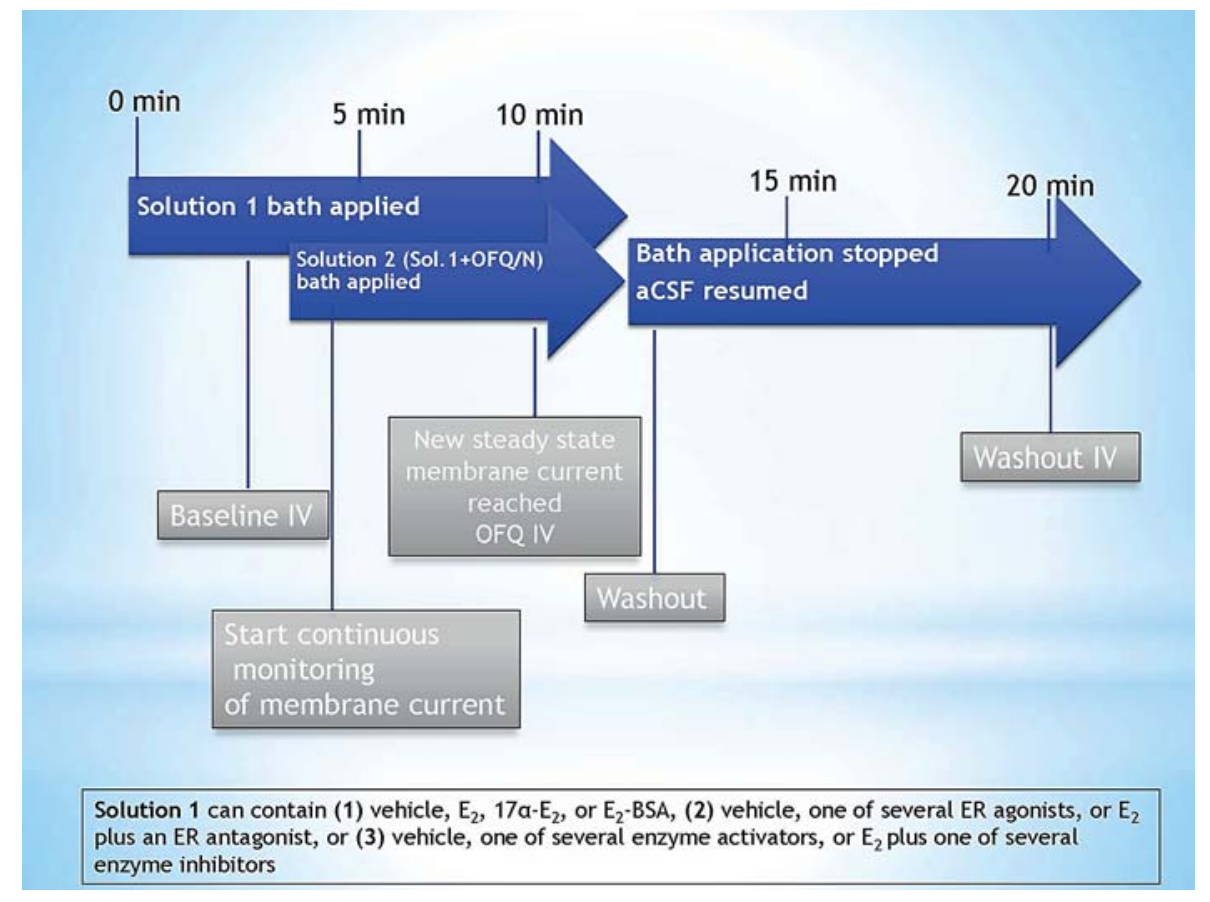

Fig. 1. Schematic representation of drug solution perfusion protocol used during electrophysiological recordings.

Fig. 2. A photomicrograph depicting a representative example of an MPN-projecting, POMC-positive, recorded ARH neuron. a Representative coronal section showing a typical injection site within the MPN and the spread of the Fluorogold after 7 days. b Biocytin labeling in the ARH neurons as visualized with streptavidin-cy2. c a-MSH immunoreactivity visualized with AF546. d Fluorogold labeling of the cell in b. e Composite overlay.
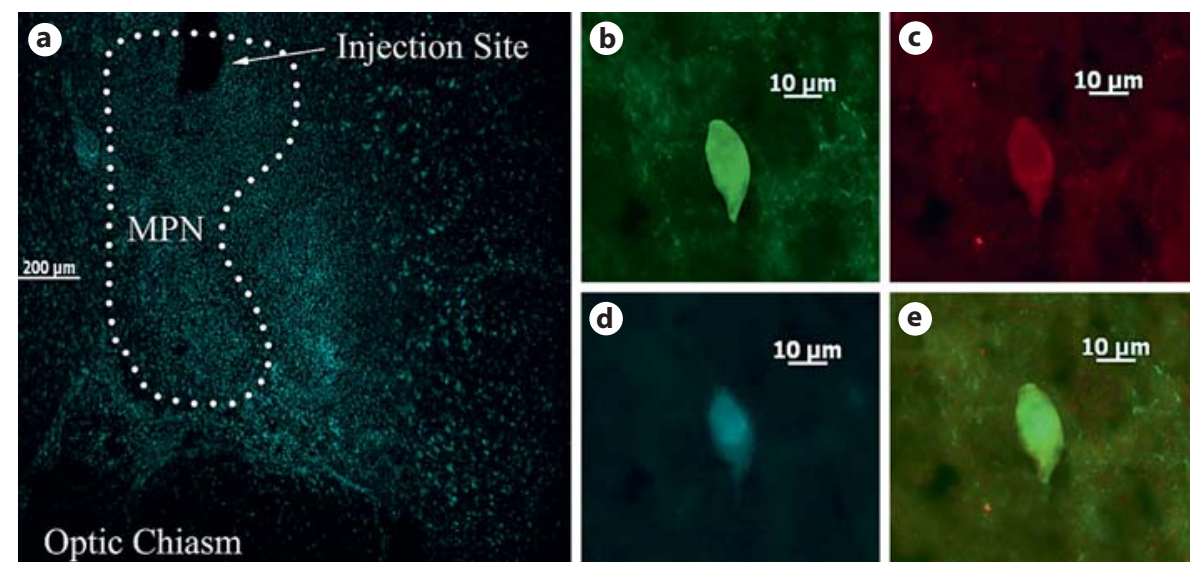

es are defined as an $\mathrm{OFQ} / \mathrm{N}$-induced hyperpolarization/outward current (and their corresponding I/V relationships) generated in the presence of the respective vehicle solutions for either $E_{2}, 17 \alpha-$ $\mathrm{E}_{2}, \mathrm{E}_{2}-\mathrm{BSA}$, ER agonists, the $\mathrm{E}_{2} / \mathrm{ER}$ antagonist cocktail, enzyme activators or the $\mathrm{E}_{2}$ /enzyme inhibitor cocktails.

\section{Immunohistochemistry}

After conducting electrophysiological recording, slices were fixed with $4 \%$ paraformaldehyde in Sorensen's phosphate buffer ( $\mathrm{pH} 7.4$ ) for 90-180 min. They were then immersed overnight in $20 \%$ sucrose dissolved in Sorensen's buffer and frozen in TissueTek embedding medium (Miles Inc., Elkhart, Ind., USA) the next day. Coronal sections $(20 \mu \mathrm{m})$ were cut on a cryostat and mounted on slides. These sections were washed with $0.1 \mathrm{M}$ sodium phosphate buffer ( $\mathrm{pH}$ 7.4) and then processed with either streptavidinCy2 (Jackson Immunoresearch Laboratories, West Grove, Pa., USA) or streptavidin-Alexa Fluor 488 (Molecular Probes Inc., Eu- gene, Oreg., USA) at a dilution of 1:300. After localizing the biocytin-filled neuron via fluorescence microscopy, the slides containing the appropriate sections were processed with polyclonal antibodies directed against either $\beta$-endorphin (Immunostar Inc., Hudson, Wis., USA; 1:400 dilution), $\alpha$-melanocyte-stimulating hormone (a-MSH, Immunostar; 1:200 dilution) or cocaine- and amphetamine-regulated transcript (Phoenix Pharmaceuticals Inc., Burlingame, Calif., USA; 1:2,000 dilution) using fluorescence immunohistochemistry $[39,40]$.

\section{Statistical Analyses}

Comparisons between two groups were made with either the Student's t test or the Mann-Whitney U test. Comparisons between more than two groups were performed using the multifactorial analysis of variance (ANOVA) followed by the least significant difference test. Differences were considered statistically significant if the alpha probability was $<0.05$. 


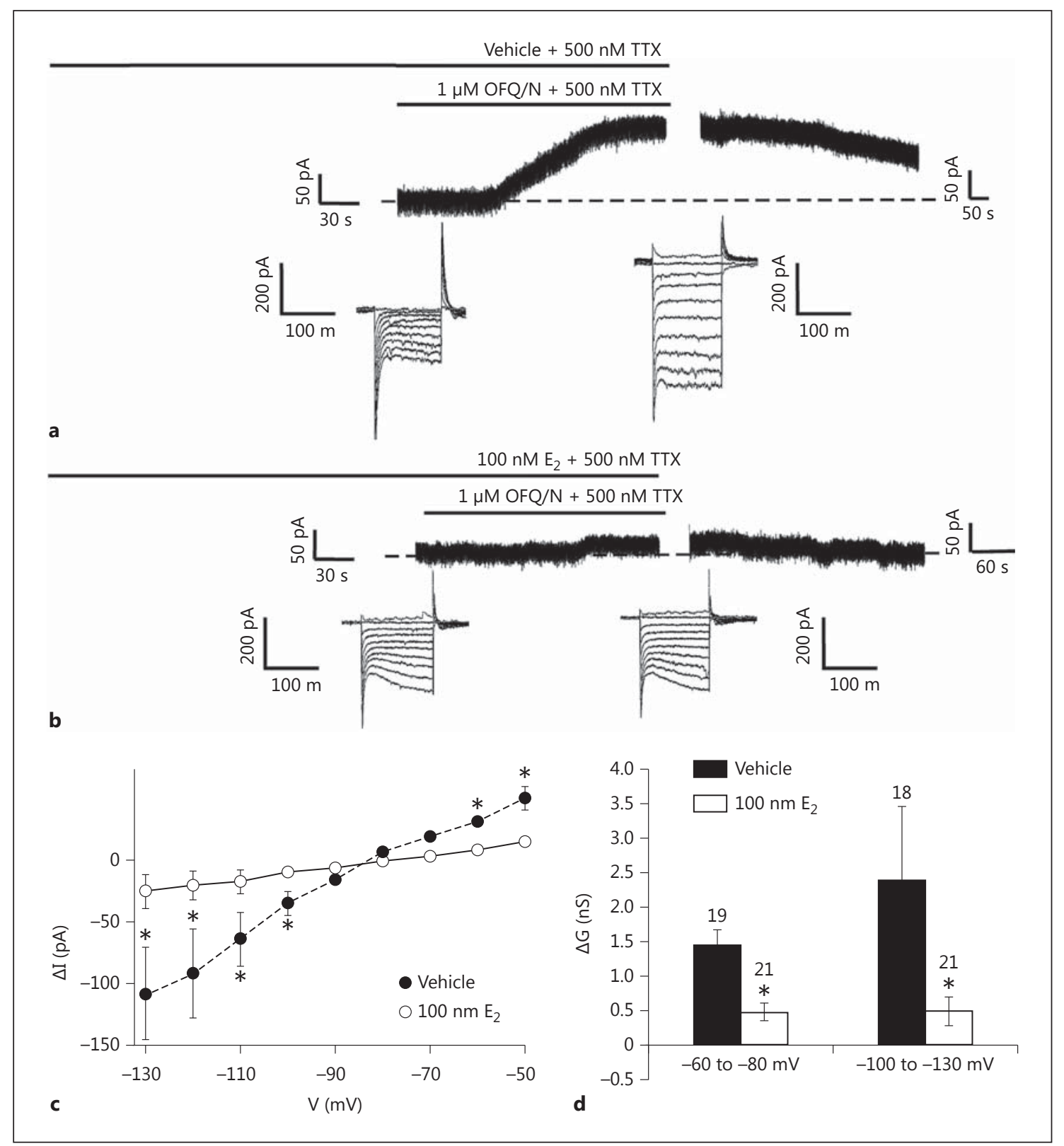

Fig. 3. Estradiol rapidly attenuates $\mathrm{OFQ} / \mathrm{N}$-induced postsynaptic currents in POMC neurons. Membrane current traces showing the $\mathrm{OFQ} / \mathrm{N}$-induced outward current observed during electrophysiological recordings from slices treated either with EtOH vehicle (a) or $\mathrm{E}_{2}(100 \mathrm{nM} ; \mathbf{b})$. The concatenated, incremental current traces

\section{Results}

Experiment 1: The Effect of OFQ/N on

$M P N-P r o j e c t i n g, A R H$ POMC Neurons

We recorded from a total of 190 hypothalamic ARH neurons. These cells exhibited a resting membrane potential of $-55.52 \pm 0.67 \mathrm{mV}$ and an $R_{\text {in }}$ of $479.33 \pm 17.99$ reflect the I/V relationships generated prior to, and in the presence of, OFQ/N. Composite I/V plot (c) and bar graph (d) illustrating the marked reduction in slope conductance $(\Delta G)$ caused by $E_{2}$. ${ }^{*} \mathrm{p}<0.05$, multifactorial ANOVA/least significant difference.

$\mathrm{M} \Omega$. Ninety-eight of these cells were immunopositive for various markers of POMC neurons, and of these POMC-positive cells, 92 projected into the MPN. All recordings followed the same perfusion and recording protocol shown in figure 1 . An example of an ARH POMC-positive neuron projecting to the MPN is represented in figure 2. 
Fig. 4. Estradiol rapidly diminishes the $\mathrm{OFQ} / \mathrm{N}$-induced hyperpolarization of POMC neurons. Membrane current traces showing the hyperpolarization caused by $\mathrm{OFQ} / \mathrm{N}$ during recordings in slices treated with $\mathrm{EtOH}$ vehicle (a) or $\mathrm{E}_{2}(\mathbf{b})$. The composite bar graph (c) shows the estrogenic reduction of the OFQ/N-induced hyperpolarization. ${ }^{*} \mathrm{p}<0.05$, Student's t test.

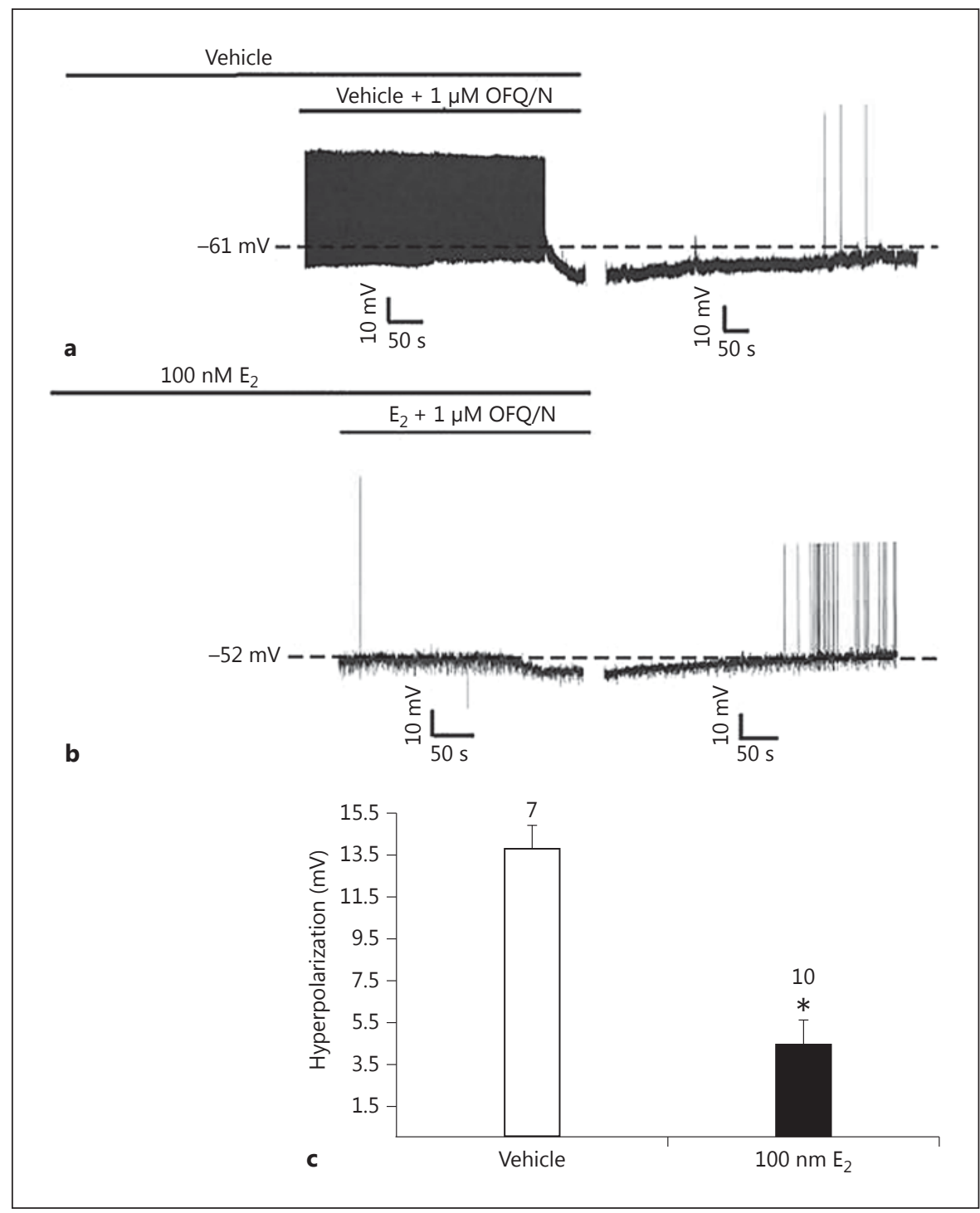

OFQ/N has been known to regulate female sexual receptivity through the inhibition of POMC neurons [40]. In vehicle-treated slices, $\mathrm{OFQ} / \mathrm{N}(1 \mu \mathrm{M})$ produces a robust outward current that reverses upon clearance of the peptide much like the current shown in figure $3 a$. This response was associated with an increase in conductance and reversed polarity near the Nernst equilibrium potential for $\mathrm{K}^{+}$. The current elicited from ARH POMC neurons from ovariectomized female rats is significantly more sizeable compared to the responses seen in unidentified/POMC-negative ARH neurons $(36.39 \pm 7.21$ vs. $13.39 \pm 3.25 \mathrm{pA}$; Student's t test, $\mathrm{t}=-2.06641, \mathrm{p}<0.05$; $\mathrm{n}=10-14)$. Therefore, all subsequent experimental analyses were performed on cellular cohorts enriched in pos- itively identified POMC neurons ( $>57 \%$ total cells) that also contained unidentified cells bearing inherent characteristics of POMC neurons (i.e., robust OFQ/N responsiveness, expression of the hyperpolarization-activated cation current and/or the A-type $\mathrm{K}^{+}$current $[35,41,42]$ ).

Experiment 2: The Receptor Subtypes through Which $E_{2}$ Rapidly Attenuates the OFQ/N Responsiveness of $M P N$-Projecting ARH POMC Neurons

In order to test our hypothesis that $\mathrm{E}_{2}$ rapidly attenuates the inhibitory actions of ORL-1 signaling, OFQ/N was bath applied to a cell in both the presence and absence of $E_{2}$. Bath application of $E_{2}(100 \mathrm{nM})$ per se for a mere 8-10 min prior to $\mathrm{OFQ} / \mathrm{N}$ had negligible effects on the 
Fig. 5. The estrogenic modulation of the $\mathrm{OFQ} / \mathrm{N}$-induced outward current in POMC neurons is stereoselective, membrane delimited and ER mediated. Membrane current traces $(\mathbf{a}-\mathbf{c})$ and composite bar graph of $\Delta \mathrm{I}$ and $\Delta \mathrm{G}(\mathbf{d})$ illustrating the attenuation of $\mathrm{OFQ} / \mathrm{N}$-induced outward current caused by $\mathrm{E}_{2}$-BSA (100 nM) but not $17 \alpha-E_{2}(100 n M)$ or $E_{2}+$ ICI $182,780(1 \mu \mathrm{M})$. $* \mathrm{p}<0.05$, Mann-Whitney U test.

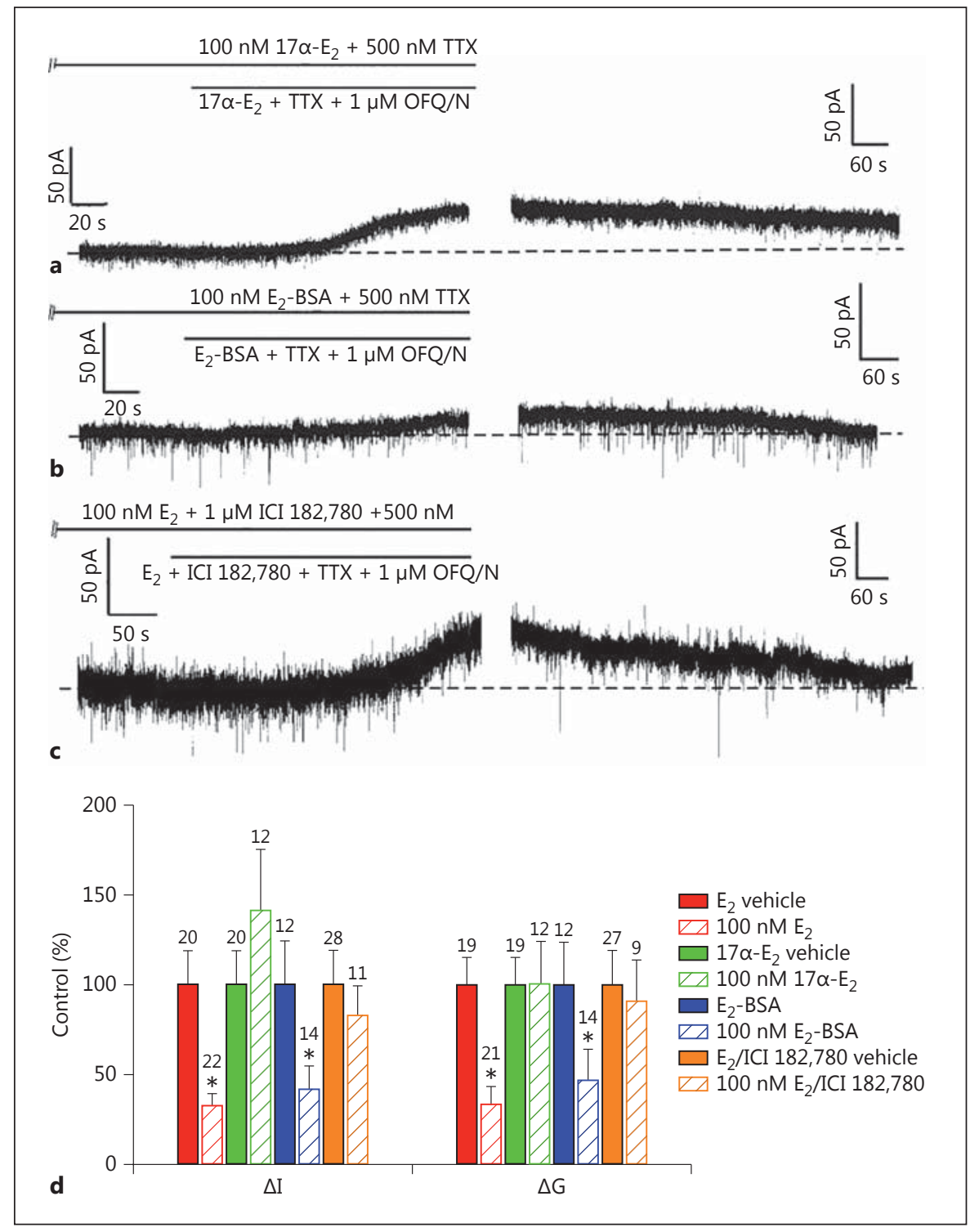

holding current $(2.94 \pm 2.54 \mathrm{pA} ; \mathrm{n}=21)$ or the slope conductance between -60 and $-80 \mathrm{mV}(0.23 \pm 0.03 \mathrm{nS} ; \mathrm{n}=$ $21)$. In the presence of $\mathrm{OFQ} / \mathrm{N}$, however, $\mathrm{E}_{2}$ markedly diminished the responsiveness of ARH POMC neurons to the neuropeptide (fig. 3b). Additionally, the composite I/V plot and conductance change (fig. 3c, d) further illustrate the attenuating effects of $\mathrm{E}_{2}$ on the $\mathrm{OFQ} / \mathrm{N}$-induced outward current (fig. $3 \mathrm{c}$ : multifactorial ANOVA, $\mathrm{F}_{\text {steroid }}=$ 15.24 , d.f. $=1, \mathrm{p}<0.0001, \mathrm{~F}_{\text {voltage }}=20.51$, d.f. $=8, \mathrm{p}<$ $0.0001, \mathrm{~F}_{\text {interaction }}=7.42$, d.f. $=8, \mathrm{p}<0.0001$; fig. $3 \mathrm{~d}$ : multifactorial ANOVA, $\mathrm{F}_{\text {steroid }}=15.24$, d.f. $=1, \mathrm{p}<0.0001$, $\mathrm{F}_{\text {voltage }}=1.69$, d.f. $=1, \mathrm{p}<0.20, \mathrm{~F}_{\text {interaction }}=1.52$, d.f. $=8$, $\mathrm{p}<0.23)$. The pronounced OFQ/N-induced outward cur- rent seen in ARH POMC neurons from vehicle-treated slices is associated with a robust and reversible hyperpolarization that leads to the cessation of firing (fig. 4a). When OFQ/N was applied in the presence of $E_{2}$, the magnitude the hyperpolarization was clearly decreased (fig. 4b). The composite graph of the hyperpolarization magnitude (fig. 4c) provides further evidence of the rapid attenuating effect of $\mathrm{E}_{2}$ (Student's $\mathrm{t}$ test, $\mathrm{t}=5.68449, \mathrm{p}<$ 0.0001).

To determine the stereospecificity of the $\mathrm{E}_{2}$-ER binding responsible for the attenuation of the $\mathrm{OFQ} / \mathrm{N}$ response, we pretreated slices with $17 \alpha-E_{2}$ instead of $E_{2}$ along with $\mathrm{OFQ} / \mathrm{N}$. In this case, the OFQ/N-induced out- 
Fig. 6. The estrogenic modulation of the OFQ/N-induced outward current in POMC neurons is due to activation of $\mathrm{G}_{\mathrm{q}}{ }^{-}$ mER and ERa. Membrane current traces (a-d) and composite bar graph of $\Delta \mathrm{I}$ and $\Delta \mathrm{G}(\mathbf{e})$ showing inhibition of the $\mathrm{OFQ} / \mathrm{N}$ induced outward current caused by the $\mathrm{G}_{\mathrm{q}}$ mER ligand STX (10 nM) and ERa agonist PPT $(1 \mu \mathrm{M})$ but not the GPR30 agonist G1 $(3 \mu \mathrm{M})$ or the ER $\beta$ agonist DPN $(3 \mu \mathrm{M})$. * $\mathrm{p}<0.05$, Mann-Whitney U test.

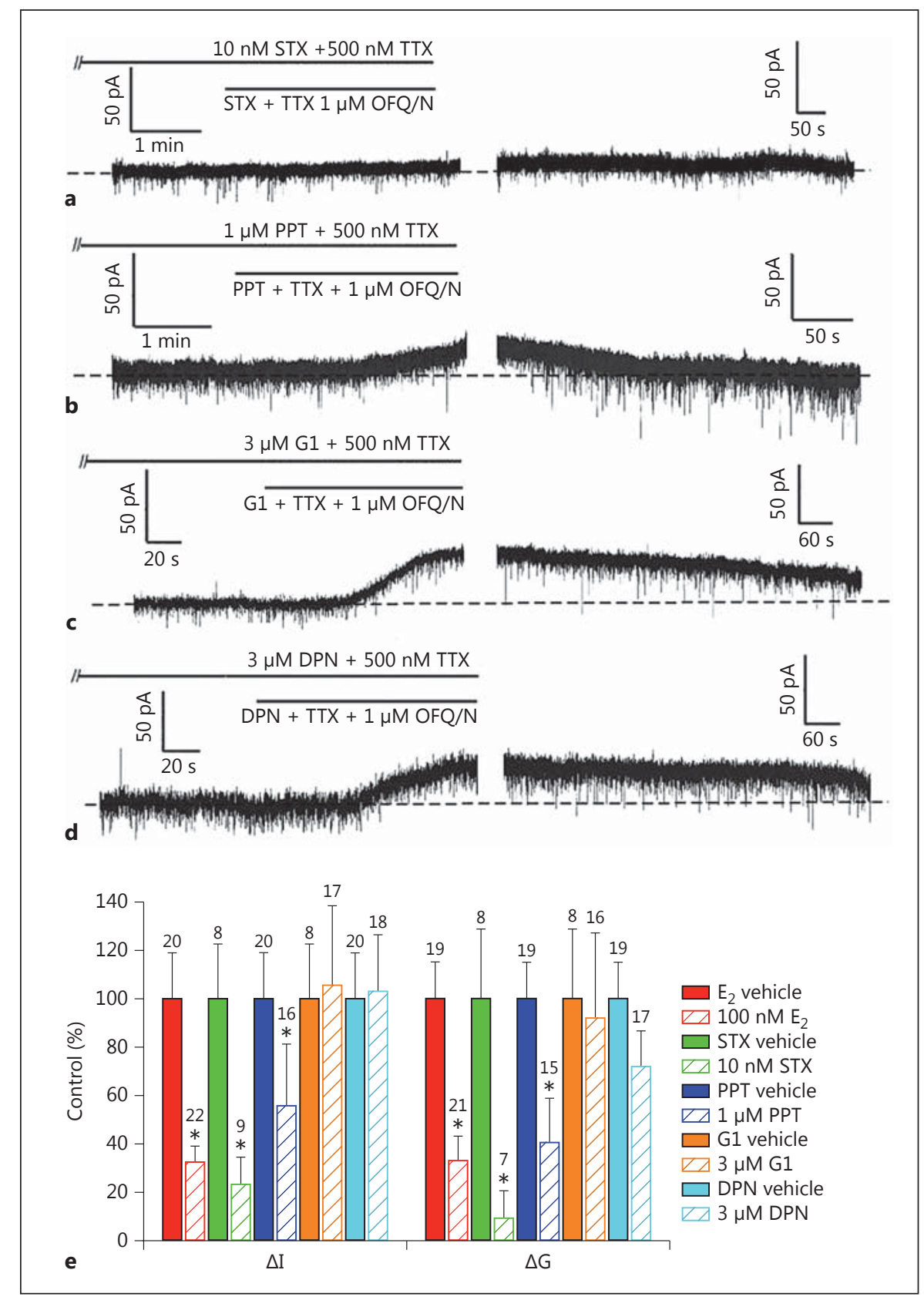

ward current was as robust as that seen in recordings from vehicle-treated control slices (fig. 5a); therefore, showing that the $\mathrm{E}_{2}$ attenuation of the $\mathrm{OFQ} / \mathrm{N}$ response is stereoselective. To test whether this estrogenic impairment is membrane initiated, we perfused the membrane impermeant $E_{2}$-BSA (100 nM) in lieu of $E_{2}$. Just as with $\mathrm{E}_{2}, \mathrm{E}_{2}$-BSA caused a significant reduction in the OFQ/Noutward current (fig. 5b), providing evidence that this $\mathrm{E}_{2}$ effect is indeed membrane delimited. However, when the
ER antagonist ICI 182,780 (1 $\mu \mathrm{M})$ was co-perfused with $\mathrm{E}_{2}$, the magnitude of the outward current was nearly identical to that observed in vehicle-treated slices (fig. 5c); providing a clear indication of the ER-mediated actions of $\mathrm{E}_{2}$. Additionally, the composite current and conductance values (fig. $5 \mathrm{~d}$ ) corroborate these findings $[\Delta \mathrm{I}$ (Mann-Whitney U test) $-\mathrm{E}_{2}: \mathrm{W}=347.0, \mathrm{p}<0.002,17 \mathrm{a}-$ $\mathrm{E}_{2}: \mathrm{W}=91.0, \mathrm{p}<0.27, \mathrm{E}_{2}-\mathrm{BSA}: \mathrm{W}=126.0, \mathrm{p}<0.04, \mathrm{E}_{2} /$ ICI 182,780: $\mathrm{W}=160.0, \mathrm{p}<0.87 ; \Delta \mathrm{G}$ (Mann-Whitney $\mathrm{U}$ 
Fig. 7. The estrogenic modulation of the OFQ/N-induced outward current in POMC neurons is dependent on the activation of PI3K. Membrane current traces (a) and composite bar graph of $\Delta \mathrm{I}$ and $\Delta \mathrm{G}$ (b) showing how the PI3K inhibitor PI828 (10 $\mu \mathrm{M})$ rescues the $\mathrm{OFQ} / \mathrm{N}$-induced outward current in the presence of $\mathrm{E}_{2} .{ }^{*} \mathrm{p}<0.05$, Mann-Whitney U test.

Fig. 8. The estrogenic modulation of the $\mathrm{OFQ} / \mathrm{N}$-induced outward current in POMC neurons is dependent on the activation of PLC. Membrane current traces (a, b) and composite bar graph of $\Delta \mathrm{I}$ and $\Delta \mathrm{G}$ (c) showing how U73122 $(20 \mu \mathrm{M})$ but not U73343 $(20 \mu \mathrm{M})$ abrogates the $\mathrm{E}_{2}$-induced attenuation of the OFQ/N-induced outward current in ARH POMC neurons. * $\mathrm{p}<0.05$, Mann-Whitney U test.
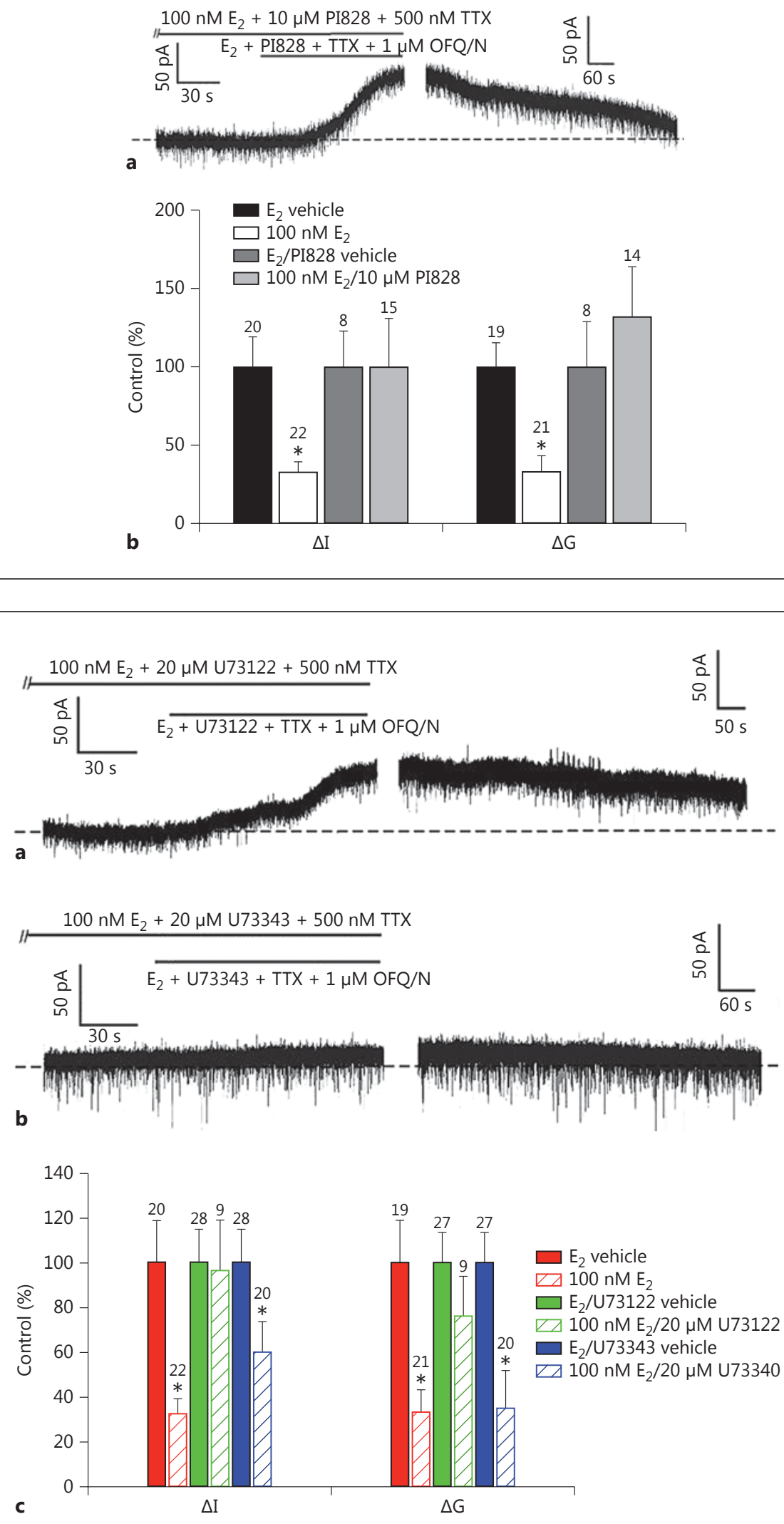
Fig. 9. The estrogenic modulation of the $\mathrm{OFQ} / \mathrm{N}$-induced outward current in POMC neurons is blocked by inhibition and mimicked by activation of PKC. Membrane current traces $(\mathbf{a}, \mathbf{b})$ and composite bar graph of $\Delta \mathrm{I}$ and $\Delta \mathrm{G}(\mathbf{c})$ showing the restoration of the OFQ/N-induced outward current caused by the PKC inhibitor NPC $15437(30 \mu \mathrm{M})$ in $\mathrm{E}_{2}$-treated slices, and the attenuation caused by the PKC activator PDBu $(1 \mu \mathrm{M})$ per se. ${ }^{*} \mathrm{p}<0.05$, MannWhitney U test.

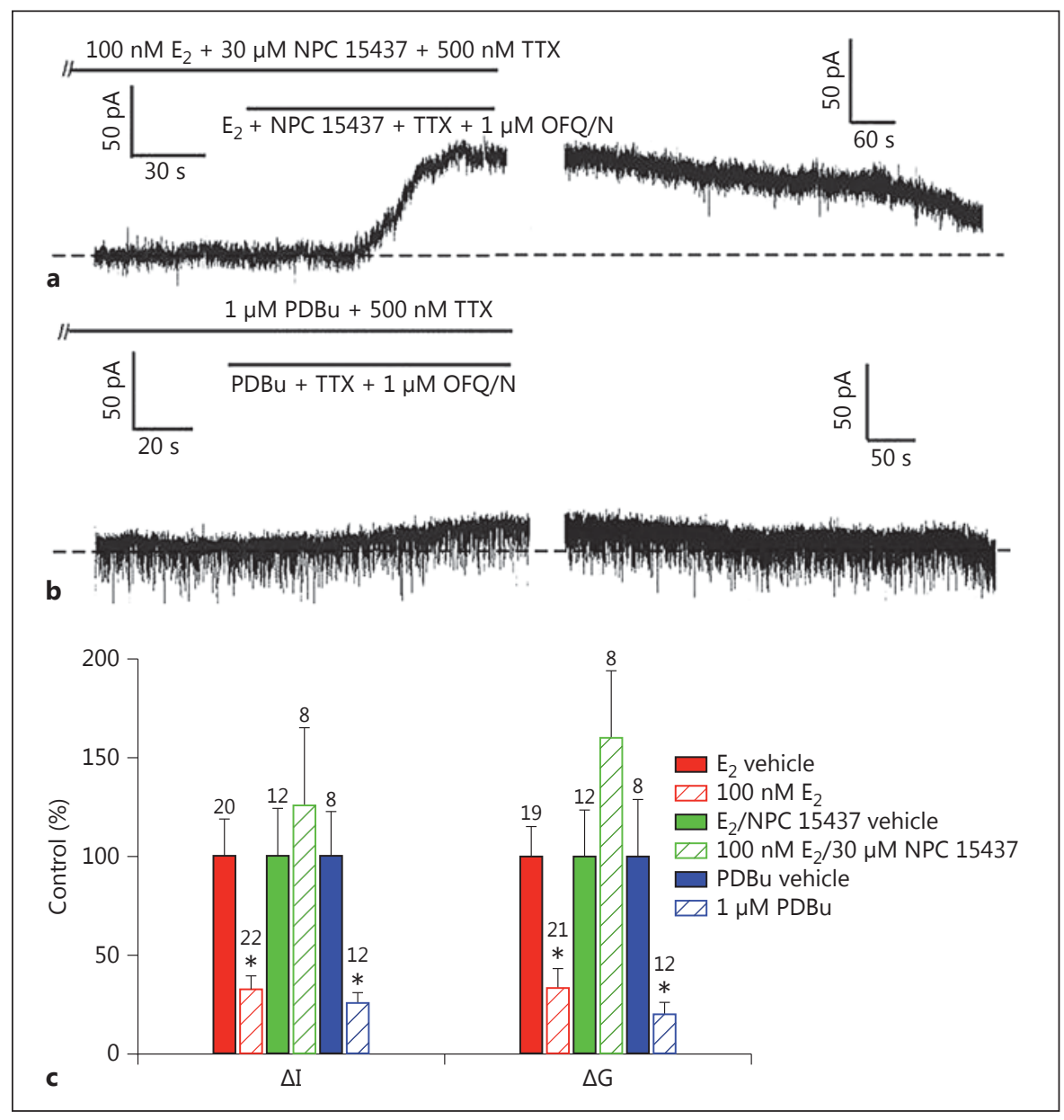

test) $-\mathrm{E}_{2}: \mathrm{W}=310.5, \mathrm{p}<0.0008,17 \alpha-\mathrm{E}_{2}: \mathrm{W}=125.5, \mathrm{p}<$ $0.66, \mathrm{E}_{2}-\mathrm{BSA}: \mathrm{W}=121.5, \mathrm{p}<0.05, \mathrm{E}_{2} / \mathrm{ICI} 182,780: \mathrm{W}=$ 92.5, $\mathrm{p}<0.56$.

Because there are multiple ER subtypes involved with $\mathrm{E}_{2}$ signaling, it was crucial to determine which are involved specifically in estrogenic diminution of the OFQ/N response in ARH POMC neurons. We thus tested the ER agonists STX, PPT, G1 and DPN that are selective for $\mathrm{G}_{\mathrm{q}^{-}}$ mER, ERa, GPR30 and ER $\beta$, respectively. Both the $\mathrm{G}_{\mathrm{q}^{-}}$ mER ligand STX (10 nM) and the ERa agonist the PPT $(1 \mu \mathrm{M})$ reduced the OFQ/N outward current [fig. $6 \mathrm{a}, \mathrm{b}$, e; $\Delta \mathrm{I}$ (Mann-Whitney U test) - STX: W $=62.0, \mathrm{p}<0.02$, PPT: $\mathrm{W}=226.0, \mathrm{p}<0.04 ; \Delta \mathrm{G}$ (Mann-Whitney U test) STX: $\mathrm{W}=49.0, \mathrm{p}<0.02$, PPT: $\mathrm{W}=209.5, \mathrm{p}<0.006]$, while the GPR30 agonist G1 $(3 \mu \mathrm{M})$ and the $\operatorname{ER} \beta(3 \mu \mathrm{M})$ agonist DPN did not [fig. 6c-e; $\Delta \mathrm{I}$ (Mann-Whitney U test) - G1: $\mathrm{W}=67.0, \mathrm{p}<0.30, \mathrm{DPN}: \mathrm{W}=192.0, \mathrm{p}<0.32 ; \Delta \mathrm{G}$ (MannWhitney U test) $-\mathrm{G} 1: \mathrm{W}=58.0, \mathrm{p}<0.27, \mathrm{DPN}$ : $\mathrm{W}=$ 183.5, $\mathrm{p}<0.07]$. Together, this shows that the $\mathrm{G}_{\mathrm{q}}-\mathrm{mER}$ and $E R a$ are responsible for the inhibition of the OFQ/N ORL-1 signaling, while GPR30 and ER $\beta$ are not.

Experiment 3: The Signal Transduction Mechanisms Underlying $E_{2}$-Mediated, Membrane-Initiated

Disruption of OFQ/N-ORL1 Signaling in

MPN-Projecting, ARH POMC Neurons

Now that we had an understanding of which ER subtypes were involved, we wanted to tease out the signaling mechanism responsible for the attenuating effects of $E_{2}$. Based on previous findings [43-45], we speculated that PI3K would be a likely upstream signaling molecule. When we administered the PI3K inhibitor PI828 $(10 \mu \mathrm{M})$ along with $\mathrm{E}_{2}$, we observed an abrogation of the estrogenic impairment of the robust outward current [fig. 7; $\Delta \mathrm{I}$ (Mann-Whitney $\mathrm{U}$ test): $\mathrm{W}=45.0, \mathrm{p}<0.35 ; \Delta \mathrm{G}$ (Mann-Whitney U test): $\mathrm{W}=67.5, \mathrm{p}<0.66]$, implicating the involvement of PI3K in the attenuation of the OFQ/N response. 
Fig. 10. The estrogenic modulation of the $\mathrm{OFQ} / \mathrm{N}$-induced outward current in POMC neurons is blocked by inhibition and mimicked by activation of PKA. Membrane current traces $(\mathbf{a}, \mathbf{b})$ and composite bar graph of $\Delta \mathrm{I}$ and $\Delta \mathrm{G}(\mathbf{c})$ showing that the estrogenic attenuation of the OFQ/N-induced outward current is reversed by the PKA inhibitor KT5720 (300 nM) and mimicked by the PKA activator Sp-cAMP (100 $\mu \mathrm{M}){ }^{*} \mathrm{p}<0.05$, Mann-Whitney U test.

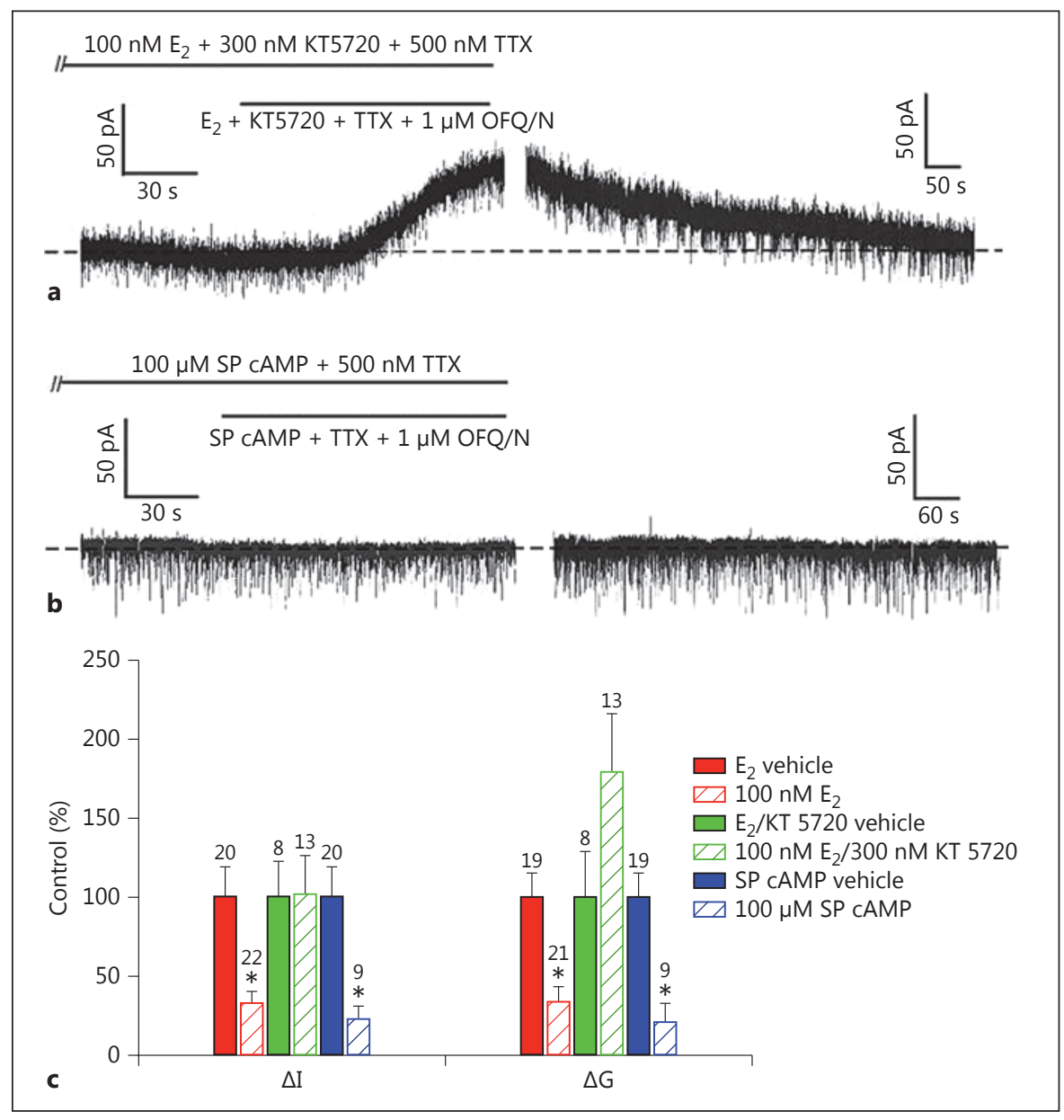

Given that the attenuation of the OFQ/N response involved the activation of $\mathrm{G}_{\mathrm{q}}$-mERs, we then wanted to see if PLC plays a role in this estrogenic signaling cascade. When the PLC inhibitor U73122 (20 $\mu \mathrm{M})$ was perfused along with $\mathrm{E}_{2}$, a robust outward current, comparable to the response in a vehicle-treated cell, was witnessed (fig. 8a). In order to assess the specificity of the compound, we also treated slices with an inactive analog of U73122 (U73343; $20 \mu \mathrm{M}$ ) along with $\mathrm{E}_{2}$. U73343 was without effect on the $\mathrm{E}_{2}$-induced inhibition of the $\mathrm{OFQ} / \mathrm{N}$ outward current (fig. 8b). The aggregate, OFQ-induced changes in current and slope conductance (fig. 8c) validate the conclusion that PLC is necessary for the estrogenic inhibition of the $\mathrm{OFQ} / \mathrm{N}$ response $[\Delta \mathrm{I}$ (MannWhitney U test $)$ - U73122: $\mathrm{W}=122.0, \mathrm{p}<0.91$, U73343: $\mathrm{W}=188.0, \mathrm{p}<0.05 ; \Delta \mathrm{G}$ (Mann-Whitney $\mathrm{U}$ test $)-\mathrm{U} 73122$ : $\mathrm{W}=140.5, \mathrm{p}<0.50, \mathrm{U} 73343: \mathrm{W}=122.5, \mathrm{p}<0.002]$.

Since PI3K and PLC were clearly essential for the attenuating effects of $E_{2}$ on the $\mathrm{OFQ} / \mathrm{N}$-induced outward current, the next logical step was to see if PKC was involved. When we perfused the PKC inhibitor NPC 15437 $(30 \mu \mathrm{M})$ along with $E_{2}$, we observed a powerful OFQ/N outward current (fig. 9a). Conversely, the PKC activator $\mathrm{PDBu}(1 \mu \mathrm{M})$ alone was able to induce an inhibition of the $\mathrm{OFQ} / \mathrm{N}$ outward current to the same extent as $\mathrm{E}_{2}$ (fig. $9 \mathrm{~b}$ ). Composite current and conductance changes provide further evidence for just how vital PKC is for the estrogenic inhibition of the OFQ/N-induced outward current [fig. 9c; $\Delta \mathrm{I}$ (Mann-Whitney U test) - NPC 15437: W = 122.0, $\mathrm{p}<0.06, \mathrm{PDBu}: \mathrm{W}=102.0, \mathrm{p}<0.002 ; \Delta \mathrm{G}$ (MannWhitney U test) - NPC 15437: W = 132.0, $\mathrm{p}<0.10$, PDBu: $\mathrm{W}=86.0, \mathrm{p}<0.05]$.

Because previous studies suggested that PKC upregulates PKA expression [36], we were interested in looking into the involvement of PKA. The PKA inhibitor KT5720 $(300 \mathrm{nM})$ perfused along with $\mathrm{E}_{2}$ reversed the estrogenic diminution of the OFQ/N-induced outward current (fig. 10a), while the cAMP activator Sp-cAMP $(100 \mu \mathrm{M})$ 
Fig. 11. The estrogenic modulation of the $\mathrm{OFQ} / \mathrm{N}$-induced outward current in POMC neurons is blocked by inhibition and mimicked by activation of nNOS. Membrane current traces $(\mathbf{a}, \mathbf{b})$ and composite bar graph of $\Delta \mathrm{I}$ and $\Delta \mathrm{G}$ (c) showing that the estrogenic diminution of the OFQ/N-induced outward current is blocked by the nNOS inhibitor NPLA (10 $\mu \mathrm{M})$ and mirrored by the NOS substrate Larginine $(30 \mu \mathrm{M}) .{ }^{*} \mathrm{p}<0.05$, Mann-Whitney $\mathrm{U}$ test.

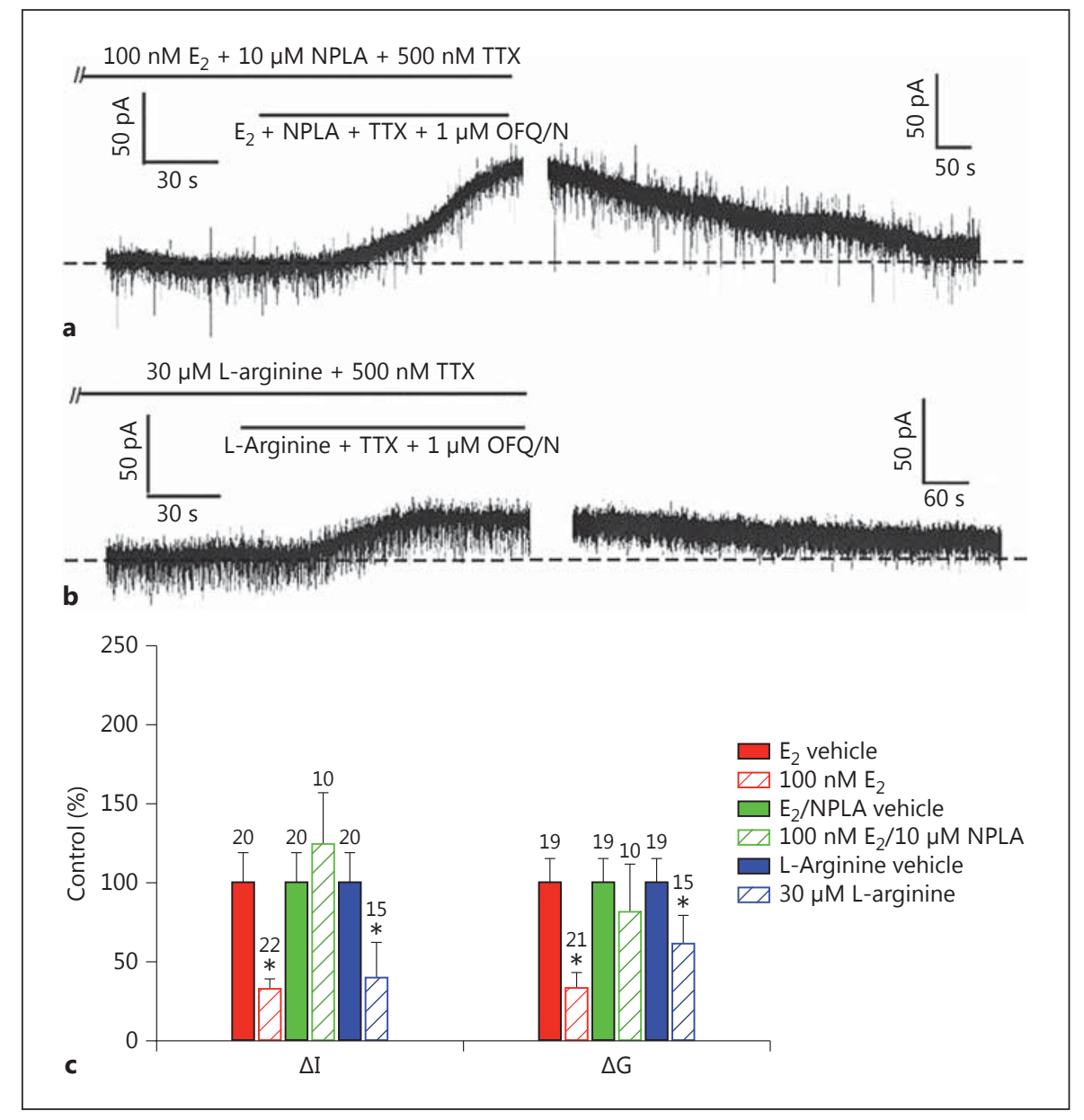

per se mimicked the effect of $E_{2}$ and suppressed the outward current (fig. 10b). The composite graph of the $\mathrm{OFQ} / \mathrm{N}$-induced changes in current and slope conductance values across the different treatment conditions corroborates these findings [fig. 10c; $\Delta \mathrm{I}$ (Mann-Whitney U test) $-\mathrm{KT} 5720: \mathrm{W}=126.0, \mathrm{p}<0.90$, Sp-cAMP: $\mathrm{W}=4.0$, $\mathrm{p}<0.002 ; \Delta \mathrm{G}$ (Mann-Whitney U test) - KT5720: $\mathrm{W}=$ 170.0, $\mathrm{p}<0.08$, Sp-cAMP: $\mathrm{W}=14.0, \mathrm{p}<0.04]$.

We have established the importance of PI3K, PLC, PKA and PKC to the estrogenic impairment of OFQ/NORL-1 signaling in ARH POMC neurons. Given that NOS has been shown to be an important downstream signaling molecule for both peripheral [43] and central [44] effects of $E_{2}$, we took the opportunity to see if nNOS was critical for this inhibition of OFQ/N to take place. When the nNOS inhibitor NPLA $(10 \mu \mathrm{M})$ was perfused along with $E_{2}$ there was, again, a very robust and reversible outward current (fig. 11a). However, when the NOS substrate L-arginine $(30 \mu \mathrm{M})$ was applied in lieu of $E_{2}$, the outward current was significantly inhibited (fig. 11b). The composite graph of the OFQ/N-induced changes in current and slope conductance across the different treatment conditions confirms these results [fig. 11c; $\Delta \mathrm{I}$ (Mann-Whitney U test) - NPLA: $\mathrm{W}=108.0, \mathrm{p}<0.75$, L-arginine: $\mathrm{W}=66.0, \mathrm{p}<0.006 ; \Delta \mathrm{G}$ (Mann-Whitney $\mathrm{U}$ test) - NPLA: $\mathrm{W}=65.0, \mathrm{p}<0.18$, L-arginine: $\mathrm{W}=85.5$, $\mathrm{p}<0.05]$.

Additionally, evidence shows that PI3K signaling in the PVN and in the vascular endothelium can produce phosphatidylinositol $(3,4,5)$ trisphosphate (PIP3) that subsequently stimulates Akt, which is then capable of activating nNOS $[43,44]$. Therefore, it was important to establish if Akt plays a role in this signaling cascade. When the Akt activator SC $79(10 \mu \mathrm{M})$ was perfused in the absence of $\mathrm{E}_{2}$, there was a reduction in the $\mathrm{OFQ} / \mathrm{N}$-induced outward current to a degree comparable with that produced by the steroid itself. Upon application of the nNOS inhibitor NPLA $(10 \mu \mathrm{M})$ in addition to SC 79 , there was a 


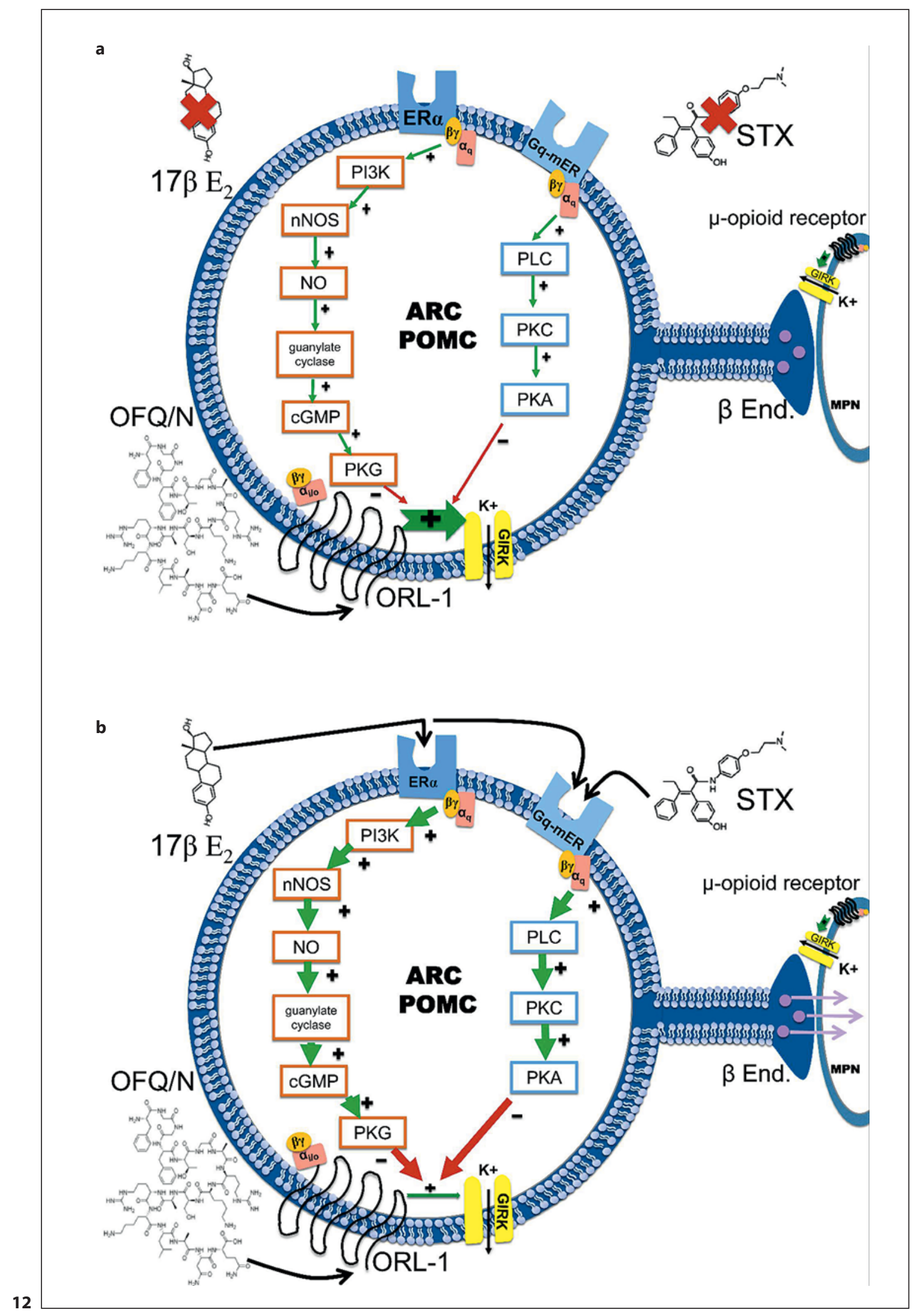

(For legend see next page.) 
clear rescuing effect that resulted in a robust $\mathrm{OFQ} / \mathrm{N}$ induced outward current (online suppl. fig. 1; see www. karger.com/doi/10.1159/000443765 for all online suppl. material).

\section{Discussion}

The present results demonstrate that $\mathrm{E}_{2}$ rapidly attenuates OFQ/N-ORL-1 coupling in MPN-projecting ARH POMC neurons serving as a critical neuroanatomical substrate in a limbic-hypothalamic circuit that regulates sexual behavior in the female rat. These findings are based on the following observations: (1) Nearly half of the recorded ARH neurons were immunopositive for antigenic markers of POMC neurons and labeled with retrograde tracer injected into the $\mathrm{MPH}$ that contains the terminal fields of these cells; (2) OFQ/N evoked a robust outward current that hyperpolarized and inhibited firing in these cells via activation of GIRK channels, which was markedly diminished upon short-term exposure to $E_{2}$. The findings also demonstrate that the attenuating effect of $\mathrm{E}_{2}$ is stereoselective, membrane-delimited and ER-mediated via activation of ER $\alpha$ and $G_{\mathrm{q}}$-mER. We base these conclusions on the observations that the $\mathrm{E}_{2}$-induced decrease in ORL-1/GIRK coupling is: (1) mimicked by the membrane impermeant $\mathrm{E}_{2}$ - $\mathrm{BSA}$ conjugate but not by the $17 \alpha$ enantiomer of $\mathrm{E}_{2}$; (2) blocked by the ER antagonist ICI 182,780, and (3) mimicked by the ERa agonist PPT and the $\mathrm{G}_{\mathrm{q}}$-mER ligand STX but not the GPR30 or ER $\beta$ agonists G1 and DPN, respectively. Lastly, our findings demonstrate this membrane-initiated estrogenic signaling utilizes a $\mathrm{PLC} / \mathrm{PKC} / \mathrm{PKA} / \mathrm{PI} 3 \mathrm{~K} / \mathrm{nNOS}$ pathway to decouple the ORL-1 receptors from their GIRK channels. We

Fig. 12. a Schematic representation of how E2 attenuates ORL-1/ GIRK coupling in MPN-projecting, ARH POMC neurons. In the absence of ER activation, ORL-1/GIRK coupling is fully functional; resulting in the robust inhibition of MPN-projecting ARH POMC neurons. $\mathbf{b} \mathrm{E}_{2}$ activation of ERa or $\mathrm{G}_{\mathrm{q}}$-mER causes the disassociation of the $\alpha_{\mathrm{q}}$ subunit to activate PLC. PLC activates PKC, which then phosphorylates adenylyl cyclase that converts ATP to cAMP. cAMP then activates PKA, which could phosphorylates either the ORL-1 receptor, RGS proteins (not shown) and/or GIRK channels. Additionally, ERa can activate PI3K, which stimulates the nNOS enzyme and subsequently guanylate cyclase that converts GTP to cGMP. cGMP activates PKG, which may also contribute to the phosphorylation of either the ORL-1 receptor, RGS proteins or GIRK channels. Collectively, this increases the excitability of MPN-projecting, ARH POMC neurons and thus the release of $\beta$-endorphin.

Rapid Estrogenic Modulation of ORL-1

Receptor Signaling base this on the fact that the $\mathrm{E}_{2}$-induced decrement in the outward current caused by OFQ/N is: (1) blocked by the PI3K inhibitor PI828, the PLC inhibitor U73122 (but not the inactive analog U73343), the PKC inhibitor NPC 15437, the PKA inhibitor KT5720 and the nNOS inhibitor NPLA, the Akt activator SC 79, and (2) mimicked by the PKC activator PDBu, the PKA activator Sp-cAMP, and the NOS substrate L-arginine.

This study provides expansive insight into preceding research on how $\mathrm{E}_{2}$ regulates sexual behavior. We know that $E_{2}$ rapidly increases $\beta$-endorphin release from $A R H$ POMC neurons, which activates $\mu$-opioid receptors expressed in neurons in the MPN $[25,26]$. The $\mathrm{E}_{2}$-induced stimulation of these POMC neurons initially suppresses lordosis, and this is essential for the subsequent expression of sexual behavior. We know this because pretreatment with the $\mu$-opioid receptor-selective antagonist naltrexone prior to the initiation of estrogen priming significantly reduces lordosis in estrogen-primed, progesterone-treated female rats to a degree similar to that observed in $\mu$-opioid receptor knockout mice $[7,11]$. Thus, the uncoupling of the ORL-1 receptor from the GIRK channel in ARH POMC neurons that we see would serve to rapidly dampen this important inhibitory influence and thereby disinhibit these cells. This could explain, at least in part, the resultant increase in $\beta$-endorphin release in the MPN, which would then recalibrate the reproductive axis and set the stage for subsequent, appropriately timed sexual receptivity. These results are also consistent with the rapid attenuation of $\mathrm{OFQ} / \mathrm{N}$-induced spinal antinociception [38]. In addition, they are in line with the rapid modulation of other neuronal elements within the reproductive axis, as $\mathrm{E}_{2}$ has long been known to directly hyperpolarize and thereby inhibit GnRH neurons within minutes of its application $[27,46]$. Moreover, the ability of $\mathrm{E}_{2}$ to rapidly disrupt the coupling of the ORL-1 receptor from the GIRK channel in ARH POMC neurons is congruent with that previously demonstrated for other metabotropic, $G_{i / o}$-coupled receptors such as the $\mu$-opioid and $\mathrm{GABA}_{\mathrm{B}}$ receptors in these cells $[23,46]$, as well as $5 \mathrm{HT}_{1 \mathrm{~A}}$ receptors in other systems $[43,44]$. Since POMC neurons innervate GnRH neurons $[47,48]$, this collective body of evidence reinforces the pleiotropism through which $\mathrm{E}_{2}$ exerts negative feedback on the reproductive axis and related behavior.

$\mathrm{G}_{\mathrm{q}}-\mathrm{mER}, \mathrm{ER} \alpha$ and GPR30 are the ERs implicated in the OFQ/N-induced spinal antinociception [38]. However, $E R a$ and $G_{q}-m E R$ have been found to play a more significant role in controlling sexual receptivity by acting on $\mathrm{G}_{\mathrm{i} / \mathrm{o}}$-coupled receptors to modulate sexual receptivity 
$[13-15,49]$. These two membrane ERs differ from each other in that STX, the selective ligand for $\mathrm{G}_{\mathrm{q}}-\mathrm{mER}$, does not bind to $\mathrm{ERa}[23,50]$. However, $\mathrm{E}_{2}$ will bind and activate both $\mathrm{ER} \alpha$ and $\mathrm{G}_{\mathrm{q}}$-mER. Additionally, these ERs have been found to facilitate the uncoupling of other receptors such as the $\mu$-opioid receptor and the $\mathrm{GABA}_{\mathrm{B}}$ receptor $[23,36,51]$. Earlier immunohistochemical studies in the rat suggested that comparatively few POMC neurons $(\sim 4 \%)$ express ERa [48]. However, more recent studies in the mouse [52] and in particular the guinea pig [53] indicate that considerably more POMC express ERa (26-29 and $74 \%$, respectively). Thus, it follows that the degree of the inhibitory effect on the OFQ/N-induced outward current in POMC neurons seen upon pretreatment with the $\mathrm{ER} \alpha$ agonist PPT would be dependent on whether ER $\alpha$ is in fact expressed in these cells. It is now well established that $\mathrm{E}_{2}$ can act within seconds to rapidly alter neuronal excitability via 'membrane-initiated steroid signaling', [24]. In order for this membrane-initiated steroid signaling to occur, ERs must first be trafficked to the plasma membrane. The localization of all sex steroid receptors to the plasma membrane caveolae rafts requires palmitoylation at a highly conserved sequence in the ligandbinding domain. Additionally, caveolin-1 is a necessary transporter of $E R \alpha$ to the rafts in the plasma membrane, and is essential for ERa-mediated regulation of sexual receptivity [49]. In cells lacking caveolin-1, endogenous ER $\alpha$ is only found intracellularly [54]. The localization of sex steroid receptors at the membrane requires the attachment of palmitic acid to an internal cysteine [54]. Palmitoylation occurs at a cysteine within a conserved 9-amino-acid motif in the ligand-binding domain [54]. Once localized to the plasma membrane, the receptors interact with scaffold and linker proteins, and can effectively activate $G$ protein $\alpha$ - and $\beta \gamma$-subunits. $G$ protein activation results in the transduction of kinase cascades that occur in seconds to minutes after receptor binding by ligand $[55,56]$. Moreover, both $\mathrm{ER} \alpha$ and $\mathrm{G}_{\mathrm{q}}-\mathrm{mER}$ can associate with metabotropic glutamate receptors in the plasma membrane $[13,18,57]$.

The present study elucidates the importance of the $\mathrm{PI} 3 \mathrm{~K} / \mathrm{PLC} / \mathrm{PKC} / \mathrm{PKA}$ pathway with regard to $\mathrm{E}_{2}$ inhibition of the OFQ/N-induced activation of GIRK channels. Our data have shown that PI3K, PLC, PKC and PKA all play a vital role in the signal transduction between $\mathrm{E}_{2}$ and the ORL-1/GIRK coupling. These findings are consistent with those found in Small et al. [38] who provided strong evidence for rapid, nongenomic effects of estrogen mediated via ERK in the modulation of ORL1-mediated antinociceptive responses to $\mathrm{OFQ} / \mathrm{N}$. Additionally, our data corroborate findings that $\mathrm{ER} \alpha$ mediates rapid $\mathrm{E}_{2}$ signal transduction via PKC that leads to MPN $\mu$-opioid receptor internalization in the regulation of sexual receptivity $[12,18]$. Finally, our findings also reflect similarities between the estrogenic effects on ORL-1/GIRK coupling and other metabotropic $G_{i / 0}$-coupled receptors such as $\mu$-opioid receptors or $\mathrm{GABA}_{B}$ receptors as both receptors couple to a GIRK channel and $\mathrm{E}_{2}$ facilitates their uncoupling through PI3K/PLC/PKC/PKA signaling $[36,45]$.

It is our thought that this signaling cascade, initiated by $E_{2}$ binding to $E R \alpha$ or the $G_{q}-m E R$, will begin with the disassociation of the $\alpha_{\mathrm{q}}$ subunit to activate PLC. PLC then converts phosphatidylinositol 4,5-bisphosphate (PIP2) to inositol 1,4,5-trisphosphate (IP3) and diacylglycerol (DAG). Recent evidence also suggests that $\alpha_{\mathrm{q}}$ can promote Akt translocation to the membrane and PI3K-dependent phosphorylation $[58,59]$. PI3K, which is an upstream mediator of $\mathrm{E}_{2}$ signaling in the $\mathrm{PVN}$ as well as in the vascular endothelium $[43,44]$, is necessary for the facilitation of $E_{2}$ uncoupling of $\mathrm{GABA}_{\mathrm{B}}$ receptors to their GIRK channels leading to $\mathrm{GABA}_{\mathrm{B}}$ desensitization [45]. PI3K synthesizes phosphatidylinositol 3-phosphates, which regulate the activity of kinases like protein kinase B (Akt; fig. 12; online suppl. fig. 1). The serine/threonine kinase Akt is the principal downstream effector of PI3K, triggering several of its cellular effects, including activation of endothelial nitric oxide synthase. Results from the present study show that activation of Akt in the absence of $E_{2}$ can mimic the estradiol-induced attenuation of the $\mathrm{OFQ} / \mathrm{N}$ induced outward current, while concomitant inhibition of the downstream nNOS will reverse the Aktinduced diminution; resulting in a robust $\mathrm{OFQ} / \mathrm{N}$ induced outward current. This shows that nNOS is stimulated downstream of Akt activation. Furthermore, the $\mathrm{E}_{2}$-induced disassociation of the $\alpha_{\mathrm{q}}$ subunit activates PLC. PLC then converts PIP2 to IP3 and DAG. Additionally, PI3K phosphorylates PIP2 to yield PIP3 and is involved with the downstream signaling. Because both PLC and PI3K utilize PIP2 as a substrate, it is important to note that the opening of GIRK channels via the activation of metabotropic $G_{i / o}$ protein-coupled receptors requires a permissive amount of PIP2, which is depleted by PLC and PI3K upon ER a and/or $G_{q}$-mER activation. Once the amount becomes insufficient, ORL-1/GIRK channel coupling becomes destabilized [60-62]. IP3 goes on to liberate intracellular calcium, and DAG activates PKC. PKC, which has been confirmed to be upstream of PKA [3], phosphorylates adenylyl cyclase, which converts ATP to cAMP. cAMP then activates PKA further downstream and phosphorylates either the GIRK channel or the ORL- 
1 receptor [63, 64], diminishing receptor/effector coupling. It is also important to keep in mind that the regulator of $G$ protein signaling (RGS) proteins also play an important role in the modulation of $G$ protein-coupled receptors through GTPase activation $[65,66]$. It has also been established that $E_{2}$ can increase the amount of RGS proteins within the PVN, and thus follows that RGSs may possibly play a role in the $\mathrm{E}_{2}$-induced uncoupling of the ORL- 1 and GIRK channels just like they do in the desensitization of $5 \mathrm{HT}_{1 \mathrm{~A}}$ receptors [67]. Thus, vital components of this mechanism have been shown in the case of the estrogenic regulation of GIRK channels linked to $\mu$-opioid and $\mathrm{GABA}_{\mathrm{B}}$ receptors, and we feel that this is reflective of what is occurring with OFQ/N-ORL-1 signaling. The convergence of ER $\alpha$ and $\mathrm{G}_{\mathrm{q}}-\mathrm{mER}$ on $\mathrm{G}_{\mathrm{q}}-\mathrm{me}-$ diated signaling pathways that diminish the coupling between $\mathrm{G}_{\mathrm{i} / \mathrm{o}}$-linked receptors and GIRK channels in POMC neurons sharply contrasts with what is observed in neuropeptide Y/agouti-related peptide neurons, in which ERa stimulation attenuates whereas $\mathrm{G}_{\mathrm{q}}$ - $\mathrm{mER}$ stimulation potentiates $\mathrm{GABA}_{\mathrm{B}}$ receptor-mediated activation of GIRK channels [51].

Additionally, we show that nNOS is involved in the ERa-mediated uncoupling of the ORL-1 and GIRK channel. This enzyme is also regulated by $\mathrm{E}_{2}$ in the $\mathrm{PVN}$, as is endothelial nitric oxide synthase in the vascular endothelium through an Src kinase (SRC)/PI3k/Akt pathway $[43,44]$, and we have shown previously that $\mathrm{E}_{2}$ increases nNOS activity in the ARH [37]. The nNOS enzyme stimulates guanylate cyclase, which will convert GTP to cGMP. The newly produced cGMP can then activate protein kinase $G$ (PKG) [68]. We suspect that the estrogenic activation of $\mathrm{PKG}$ can also contribute to the phosphorylation of either the ORL-1 receptor, RGS proteins or GIRK channel, thus leading to a disinhibition of MPN-project- ing, ARH POMC neurons and a suppression of lordotic behavior (fig. 12). Alternatively, nNOS-induced formation of nitric oxide can lead to s-nitrosylation of thiol groups on cysteine residues in signaling molecules, ion channels, as well as ionotropic and metabotropic receptors, resulting in an alteration in the function of these proteins $[69,70]$. Thus, it is possible that the $\mathrm{E}_{2}$-induced activation of nNOS causes s-nitrosylation that uncouples the ORL-1 receptor from its effector systems, as has been shown for other $G_{i / o}$-linked receptors like the M2 muscarinic receptor [70].

In conclusion, $\mathrm{E}_{2}$ rapidly attenuates the ORL-1 receptor-mediated inhibition of POMC neurons in female rats by activating the $\mathrm{PI} 3 \mathrm{~K} / \mathrm{PLC} / \mathrm{PKC} / \mathrm{PKA} / \mathrm{Akt} / \mathrm{nNOS}$ pathways. $E_{2}$ exerts far-reaching effects on vital, everyday physiological functions. When there is a defect in $\mathrm{E}_{2}$ biosynthesis, bioavailability or ER-mediated signal transduction, there will be a clear decrease in quality of life. The unfortunate symptoms of such abnormalities can affect ovulation and uterine development that underlie fertility, not to mention bone density, cardiovascular function and memory [4]. By gaining a better understanding of the signal transduction mechanisms through which $\mathrm{E}_{2}$ disrupts the coupling of ORL-1 receptors to their GIRK channels at a critical neuroanatomical substrate within the limbic-hypothalamic circuitry controlling female sexual receptivity, we can develop better treatments to fit individual needs for the treatment of infertility or the regulation of fertility.

\section{Acknowledgements}

This study was supported by PHS grants DA024314, HD058638 and NS038809, as well as intramural funding from Western University of Health Sciences.

\section{References}

1 Saldanha CJ, Remage-Healey L, Schlinger BA: Synaptocrine signaling: steroid synthesis and action at the synapse. Endocr Rev 2011;32: 532-549.

- Sinchak K, Wagner EJ: Estradiol signaling in the regulation of reproduction and energy balance. Front Neuroendocrinol 2012;33: 342-363.

-3 Kelly MJ, Wagner EJ: Estrogen modulation of G-protein-coupled receptors. Trends Endocrinol Metab 1999;10:369-374.
4 Wend K, Wend P, Krum SA: Tissue-specific effects of loss of estrogen during menopause and aging. Front Endocrinol DOI: 10.3389/ fendo.2012.00019.

5 Czaja JA, Goldfoot DA, Karavolas HJ: Comparative facilitation and inhibition of lordosis in the guinea pig with progesterone, $5 a-$ pregnane-3,20-dione, or 3a-hydroxy-5apregnane-20-one. Horm Behav 1974;5:261274.

6 Sinchak K, Hendricks DG, Baroudi R, Micevych PE: Orphanin FQ/nociceptin in the ventromedial nucleus facilitates lordosis in female rats. Neuroreport 1997;8:3857-3860.
7 Sinchak K, Shahedi K, Dewing P, Micevych $P E$ : Sexual receptivity is reduced in the female mu-opioid receptor knockout mouse. Neuroreport 2005; 16:1697-1700.

8 Terasawa E, Wiegand SJ: Effects of hypothalamic deafferentation on ovulation and estrous cyclicity in the female guinea pig. Neuroendocrinology 1978;26:229-248.

-9 Pawluski JL, Brummelte S, Barha CK, Crozier TM, Galea LAM: Effects of steroid hormones on neurogenesis in the hippocampus of the adult female rodent during the estrous cycle, pregnancy, lactation and aging. Front Neuroendocrinol 2009;30:343-357.
Rapid Estrogenic Modulation of ORL-1 Receptor Signaling 
10 Davis BL, Manzanares J, Lookingland KJ, 22 Kuo J, Hamid N, Bondar G, Prossnitz ER, Moore KE, Clemens LG: Noradrenergic innervation to the VMN is not necessary for lordosis. Pharmacol Biochem Behav 1991;39: 737-742.

11 Torii M, Kubo K, Sasaki T: Naloxone and initial estrogen action to induce lordosis in ovariectomized rats: the effect of a cut between the septum and preoptic area. Neurosci Lett 1995;195:167-170.

12 Dewing P, Christensen A, Bondar G, Micevych PE: Protein kinase $\mathrm{C}$ signaling in the hypothalamic arcuate nucleus regulates sexual receptivity in female rats. Endocrinology 2008;149:5934-5942.

13 Christensen A, Micevych PE: A novel membrane estrogen receptor activated by STX induces female sexual receptivity through an interaction with mGluR1a. Neuroendocrinology 2013;97:363-368.

14 Mahavongtrakul M, Kanjiya MP, Maciel M, Kanjiya S, Sinchak K: Estradiol dose-dependent regulation of membrane estrogen receptor- $\alpha$, metabotropic glutamate receptor$1 \mathrm{a}$, and their complexes in the arcuate nucleus of the hypothalamus in female rats. Endocrinology 2013;154:3251-3260.

-15 Mazzucco CA, Walker HA, Pawluski JL, Lieblich SE, Galea LAM: ER $\alpha$, but not ER $\beta$, mediates the expression of sexual behavior in the female rat. Behav Brain Res 2008;191:111117.

16 Konigame VC, Siu ER, Royer C, Lucas TFG, Porto CS, Abdalla FMF: Estrogen receptors mediate rapid activation of phospholipase $\mathrm{C}$ pathway in rat endometrium. Steroids 2011; 76:1582-1589.

-17 Krege JH, Hodgin JB, Couse JF, Enmark E, Warner M, Mahler JF, Sar M, Korach KS, Gustafsson J-Å, Smithies O: Generation and reproductive phenotypes of mice lacking estrogen receptor $\beta$. Proc Natl Acad Sci USA 1998;95:15677-15682.

18 Dewing P, Boulware MI, Sinchak K, Christensen A, Mermelstein PG, Micevych PE: Membrane estrogen receptor- $\alpha$ interactions with metabotropic glutamate receptor 1a modulate female receptivity in rats. J Neurosci 2007;27:9294-9300.

19 Prossnitz ER, Barton M: Estrogen biology: new insights into GPER function and clinical opportunities. Mol Cell Endocrinol 2014;389: 71-83.

20 Filardo EJ, Quinn JA, Bland KI, Frackelton AR: Estrogen-induced activation of Erk-1 and Erk-2 requires the $G$ protein-coupled receptor homolog, GPR30, and occurs via transactivation of the epidermal growth factor receptor through release of HB-EGF. Mol Endocrinol 2000;14:1649-1660.

-21 Long N, Serey C, Sinchak K: $17 \beta$-estradiol rapidly facilitates lordosis through $\mathrm{G}$ proteincoupled estrogen receptor 1 (GPER) via deactivation of medial preoptic nucleus $\mu$-opioid receptors in estradiol primed female rats. Horm Behav 2014;66:663-666. Micevych PE: Membrane estrogen receptors stimulate intracellular calcium release and progesterone synthesis in hypothalamic astrocytes. J Neurosci 2010;30:12950-12957.

23 Qiu J, Bosch MA, Tobias SC, Krust A, Graham SM, Murphy SJ, Korach KS, Chambon P, Scanlan TS, Rønnekleiv OK, Kelly MJ: A Gprotein-coupled estrogen receptor is involved in hypothalamic control of energy homeostasis. J Neurosci 2006;26:5649-5655.

24 Roepke TA, Ronnekleiv OK, Kelly MJ: Physiological consequences of membrane-initiated estrogen signaling in the brain. Front Biosci 2011;16:1560-1573.

25 Ferin M, Van Vugt D, Wardlaw S: The hypothalamic control of the menstrual cycle and the role of endogenous opioid peptides. Recent Prog Horm Res 1984;40:441-485.

26 Eckersell CB, Popper P, Micevych PE: Estrogen-induced alteration of $\mu$-opioid receptor immunoreactivity in the medial preoptic nucleus and medial amygdala. J Neurosci 1998; 18:3967-3976.

27 Kelly MJ, Ronnekleiv OK, Eskay RL: Identification of estrogen-responsive LHRH neurons in the guinea pig hypothalamus. Brain Res Bull 1984;12:399-407.

28 Wagner EJ, Rønnekleiv OK, Kelly MJ: The noradrenergic inhibition of an apamin-sensitive, small conductance $\mathrm{Ca}^{2+}$-activated $\mathrm{K}^{+}$ channel in hypothalamic GABAergic neurons: pharmacology, estrogen sensitivity and relevance to the control of the reproductive axis. J Pharmacol Exp Ther 2001;299:21-30.

29 Qiu J, Bosch MA, Jamali K, Xue C, Kelly MJ, Rønnekleiv OK: Estrogen upregulates T-type calcium channels in the hypothalamus and pituitary. J Neurosci 2006;26:11072-11082.

30 Bunzow JR, Saez C, Mortrud M, Bouvier C, Williams JT, Low M, Grandy DK: Molecular cloning and tissue distribution of a putative member of the rat opioid receptor gene family that is not a $\mu, \delta$ or kappa opioid receptor type. FEBS Lett 1994;347:284-288.

31 Sinchak K, Romeo HE, Micevych PE: Sitespecific estrogen and progestin regulation of orphanin FQ/nociceptin and nociceptin opioid receptor mRNA expression in the female rat limbic hypothalamic system. J Comp Neu-

- 32 Sanathara NM, Moreas J, Mahavongtrakul M, Sinchak K: Estradiol upregulates progesterone receptor and orphanin FQ colocalization in arcuate nucleus neurons and opioid receptor-like receptor-1 expression in proopiomelanocortin neurons that project to the medial preoptic nucleus in the female rat. Neuroendocrinology 2014;100:103-118.

33 Wagner EJ, Rønnekleiv OK, Grandy DK, Kelly MJ: The peptide orphanin FQ inhibits $\beta$-endorphin neurons and neurosecretory cells in the hypothalamic arcuate nucleus by activating an inwardly-rectifying $\mathrm{K}^{+}$conductance. Neuroendocrinology 1998;67:73-82. rol 2006;496:252-268
4 Farhang B, Pietruszewski L, Lutfy K, Wagner EJ: The role of the NOP receptor in regulating food intake, meal pattern, and the excitability of proopiomelanocortin neurons. Neuropharmacology 2010;59:190-200.

- 35 Borgquist A, Kachani M, Tavitian N, Sinchak $\mathrm{K}$, Wagner EJ: Estradiol negatively modulates the pleiotropic actions of orphanin FQ/nociceptin at proopiomelanocortin synapses. Neuroendocrinology 2013;98:60-72.

36 Kelly MJ, Rønnekleiv OK, Ibrahim N, Lagrange $\mathrm{AH}$, Wagner EJ: Estrogen modulation of $\mathrm{K}^{+}$channel activity in hypothalamic neurons involved in the control of the reproductive axis. Steroids 2002;67:447-456.

-37 Borgquist A, Meza C, Wagner EJ: Role of neuronal nitric oxide synthase in the estrogenic attenuation of cannabinoid-induced changes in energy homeostasis. J Neurophysiol 2015; 113:904-914.

38 Small KM, Nag S, Mokha SS: Activation of membrane estrogen receptors attenuates opioid receptor-like1 receptor-mediated antinociception via an ERK-dependent non-genomic mechanism. Neuroscience 2013;255:177190.

39 Ho J, Cox JM, Wagner EJ: Cannabinoid-induced hyperphagia: correlation with inhibition of proopiomelanocortin neurons? Physiol Behav 2007;92:507-519.

40 Borgquist A, Rivas VM, Kachani M, Sinchak K, Wagner EJ: Gonadal steroids differentially modulate the actions of orphanin FQ/nociceptin at a physiologically relevant circuit controlling female sexual receptivity. J Neuroendocrinol 2014;26:329-340.

41 Ibrahim N, Bosch MA, Smart JL, Qiu J, Rubinstein M, Rønnekleiv OK, Low MJ, Kelly MJ: Hypothalamic proopiomelanocortin neurons are glucose responsive and express $\mathrm{K}_{\mathrm{ATP}}$ channels. Endocrinology 2003; 144: 1331-1340.

42 Kellert BA, Nguyen MC, Nguyen C, Nguyen $\mathrm{QH}$, Wagner EJ: Estrogen rapidly attenuates cannabinoid-induced changes in energy homeostasis. Eur J Pharmacol 2009;622:15-24.

43 Haynes MP, Li L, Sinha D, Russell KS, Hisamoto K, Baron R, Collinge M, Sessa WC, Bender JR: Src kinase mediates phosphatidylinositol 3-kinase/Akt-dependent rapid endothelial nitric-oxide synthase activation by estrogen. J Biol Chem 2003;278:2118-2123.

44 Gingerich S, Krukoff TL: Activation of ER $\beta$ increases levels of phosphorylated nNOS and NO production through a Src/PI3K/Akt-dependent pathway in hypothalamic neurons. Neuropharmacology 2008;55:878-885.

45 Malyala A, Zhang C, Bryant DN, Kelly MJ, Rønnekleiv OK: PI3K signaling effects in hypothalamic neurons mediated by estrogen. J Comp Neurol 2008;506:895-911.

46 Lagrange AH, Ronnekleiv OK, Kelly MJ: Estradiol-17 $\beta$ and $\mu$-opioid peptides rapidly hyperpolarize GnRH neurons: a cellular mechanism of negative feedback. Endocrinology 1995; 136:2341-2344. 
-47 Naftolin F, Leranth C, Horvath TL, GarciaSegura LM: Potential neuronal mechanisms of estrogen actions in synaptogenesis and synaptic plasticity. Cell Mol Neurobiol 1996; 16:213-223.

48 Simonian SX, Spratt DP, Herbison AE: Identification and characterization of estrogen receptor $\alpha$-containing neurons projecting to the vicinity of the gonadotropin-releasing hormone perikarya in the rostral preoptic area of the rat. J Comp Neurol 1999;411:346-358.

49 Christensen A, Micevych PE: CAV1 siRNA reduces membrane estrogen receptor- $\alpha$ levels and attenuates sexual receptivity. Endocrinology 2012;153:3872-3877.

50 Qiu J, Bosch MA, Tobias SC, Grandy DK, Scanlan TS, Rønnekleiv OK, Kelly MJ: Rapid signaling of estrogen in hypothalamic neurons involves a novel G-protein-coupled estrogen receptor that activates protein kinase C. J Neurosci 2003;23:9529-9540.

-51 Smith AW, Bosch MA, Wagner EJ, Rønnekleiv OK, Kelly MJ: The membrane estrogen receptor ligand STX rapidly enhances GABAergic signaling in NPY/AgRP neurons: role in mediating the anorexigenic effects of $17 \beta$-estradiol. Am J Physiol Endocrinol Metab 2013;305:E362-E640.

- 52 de Souza FSL, Nasif S, López-Leal R, Levi DH, Low MJ, Rubinstein M: The estrogen receptor a colocalizes with proopiomelanocortin in hypothalamic neurons and binds to a conserved motif present in the neuron-specific enhancer nPE2. Eur J Pharmacol 2011;660: 181-187.

53 Roepke TA, Malyala A, Bosch MA, Kelly MJ, Rønnekleiv OK: Estrogen regulation of genes important for $\mathrm{K}^{+}$channel signaling in the arcuate nucleus. Endocrinology 2007; 148: 4937-4951.
54 Pedram A, Razandi M, Sainson RCA, Kim JK, Hughes CC, Levin ER: A conserved mechanism for steroid receptor translocation to the plasma membrane. J Biol Chem 2007;282: 22278-22288.

55 Levin ER: Cellular functions of plasma membrane estrogen receptors. Steroids 2002;67: 471-475.

56 Razandi M, Alton G, Pedram A, Ghonshani S, Webb P, Levin ER: Identification of a structural determinant necessary for the localization and function of estrogen receptor $\alpha$ at the plasma membrane. Mol Cell Biol 2003;23: 1633-1646.

57 Boulware MI, Weick JP, Becklund BR, Kuo SP, Groth RD, Mermelstein PG: Estradiol activates group I and II metabotropic glutamate receptor signaling, leading to opposing influences on cAMP response element-binding protein. J Neurosci 2005;25:5066-5078.

58 Sánchez-Fernández G, Cabezudo S, GarcíaHoz C, Benincá C, Aragay AM, Mayor F, Ribas C: Gaq signalling: the old and the new. Cell Signal 2014;26:833-848.

59 Badolia R, Manne BK, Dangelmaier C, Chernoff J, Kunapuli SP: Gq-mediated Akt translocation to the membrane: a novel $\mathrm{PIP}_{3}$-independent mechanism in platelets. Blood 2015; 125:175-184.

60 Sui JL, Petit-Jacques J, Logothetis D: Activation of the atrial KAch channel by the $\beta \gamma$ subunits of $\mathrm{G}$ proteins or intracellular $\mathrm{Na}^{+}$ions depends on the presence of phosphatidylinositol phosphates. Proc Natl Acad Sci USA 1998;95:1307-1312.

61 Huang C-L, Feng S, Hilgemann DW: Direct activation of inward rectifier potassium channels by $\mathrm{PIP}_{2}$ and its stabilization by $\mathrm{G} \beta \gamma$. Nature 1998;391:803-806.

62 Lei Q, Jones MB, Talley EM, Garrison JC, Bayliss DA: Molecular mechanisms mediating inhibition of $\mathrm{G}$ protein-coupled inwardly-rectifying $\mathrm{K}^{+}$channels. Mol Cells 2003;15: $1-9$.
63 Harada H, Ueda H, Wada Y, Katada T, Ui M, Satoh M: Phosphorylation of $\mu$-opioid receptors - a putative mechanism of selective uncoupling of receptor - Gi interaction, measured with low- $\mathrm{K}_{\mathrm{m}}$ GTPase and nucleotidesensitive agonist binding. Neurosci Lett 1989; 100:221-226.

64 Harada H, Ueda H, Katada T, Ui M, Satoh M: Phosphorylated $\mu$-opioid receptor purified from rat brain lacks functional coupling with $\mathrm{G}_{\mathrm{i}} \mathrm{l}$, a GTP-binding protein in reconstituted lipid vesicles. Neurosci Lett 1990;113:47-49.

65 Zhang P, Mende U: Regulators of G-protein signaling in the heart, and their potential as therapeutic targets. Circ Res 2011;109:320333.

66 Stewart A, Fisher RA: Introduction: G protein-coupled receptors and RGS proteins. Prog Mol Biol Transl Sci 2015;133:1-11.

-67 Carrasco GA, Barker SA, Zhang Y, Damjanoska KJ, Sullivan NR, Garcia F, D'Souza DN, Muma NA, Van de Kar LD: Estrogen treatment increases the levels of regulator of $\mathrm{G}$ protein signaling-Z1 in the hypothalamic paraventricular nucleus: possible role in desensitization of 5-hydroxytryptamine ${ }_{1 \mathrm{~A}}$ receptors. Neuroscience 2004;127:261-267.

68 Gao Y, Dhanakoti S, Tolsa J-F, Raj JU: Role of protein kinase $\mathrm{G}$ in nitric oxide- and cGMPinduced relaxation of newborn ovine pulmonary veins. J Appl Physiol 1999;87:993-998.

69 Jaffrey SR, Erdjument-Bromage H, Ferris CD, Tempst P, Snyder SH: Protein S-nitrosylation: a physiological signal for neuronal nitric oxide. Nat Cell Biol 2001;3:193-197.

70 Daaka Y: S-nitrosylation-regulated GPCR signaling. Biochim Biophys Acta 2012;1820: 743-751. 